Linköping University Medical Dissertations No. 1391.

\title{
Heart failure in primary care with special emphasis on costs and benefits of a disease management programme
}

\author{
Björn Agvall
}

General Practice

Department of Medical and Health Sciences

Linköpings Universitet, Sweden

58183 Linköping

www.liu.se

Linköping University

Linköping 2014

ISBN: 978-91-7519-424-0 
Nothing is impossible. The impossible just takes a little longer.

Winston Churchill 


\section{CONTENTS}

ABSTRACT

LIST OF PAPERS

ABBREVIATIONS

INTRODUCTION

Background

Definition of heart failure

Aetiology and comorbidity

Epidemiology

Prognosis

Diagnostics of heart failure

Symptoms and signs

Laboratory blood tests

Natriuretic peptides

Electrocardiography

Chest X-ray

Cardiac function

Treatment of heart failure

Non-pharmacologic treatment

ACE inhibitors

Angiotensin receptor blockers

Beta-blockers

Mineralocorticoid receptor antagonist

Digoxin

Diuretics

Heart failure in primary care

Heart failure management programme

Healthcare utilization of heart failure

AIMS OF THE STUDY

General aim

Specific aim 


\section{POPULATIONS AND METHODS}

Population (I)

Population (II)

Populations (III,IV)

Method (I)

Method (II)

Data collection

Resource utilization

Method (III,IV)

Stratification

The intervention

The study process

Ecohcardiography

Blood sampling and NT-proBNP measurement

Measurements of quality of life and functional capacity

Evaluation of composite endpoints

Assessed resource utilization

\section{Statistics}

\section{Ethics}

\section{RESULTS}

Results (I)

Distribution of age

Etiological factors and concomitant diseases

Diagnostics of heart failure in primary healthcare

Treatment of heart failure in primary healthcare

\section{Results (II)}

Cardiac function according to echocardiography

Comorbidity in patients with HF in the PHC

The pharmacological treatment of heart failure

The resource utilization for patients with heart failure

\section{Results (III,IV)}

The baseline characteristics

Medication 
Compilation of composite endpoints

NYHA functional classes

Cardiac function with echocardiography

Cardiac function assessed with natriuretic peptides

The assessment of health related quality of life

Utilization of health care resources

\section{DISCUSSION}

Population characteristics

Etiological factors and concomitant diseases in heart failure

Diagnostic considerations of heart failure in primary health care

The use of medication in heart failure

Functional capacity of the heart failure

Evaluation of the composite endpoints

Natriuretic peptides

Cardiac function

Assessment of Quality of life

The resource utilization

Health care costs

\section{Limitations of the research}

The implementation of the research

Future research

\section{Conclusions}

The research implications

\section{GRANTS}

SUMMARY IN SWEDISH

ACKNOWLEDGEMENTS

REFERENCES 


\begin{abstract}
Background and aim. Heart failure (HF) is a common condition associated with poor quality of life (QoL), high morbidity and mortality and is frequently occurring in primary health care (PHC). It involves a substantial economic burden on the health care expenditure. There are modern pharmacological treatments with evident impact on QoL, morbidity, mortality, and proved to be cost-effective. Despite this knowledge, the treatment of HF is considered somewhat insufficient. There are several HF management programmes (HFMP) showing beneficial effects but these studies is predominantly based in hospital care (HC).

The first aim of this thesis was to describe patients with HF in the PHC regarding gender differences, diagnosis, treatment and health related costs (I, II). The second aim was to evaluate whether HFMP have beneficial effects in the PHC regarding cardiac function, quality of life, health care utilization and health care-related costs (III,IV).
\end{abstract}

Methods. The initial study involved retrospective collection of data from 256 patients with symptomatic HF in PHC (I). The data collected were gender, age, diagnostics and ongoing treatment. The second study was an economic calculation performed on 115 patients (II). The economic data was retrospectively retrieved as the number of hospital days, visits to nurses and physicians in $\mathrm{HC}$ and $\mathrm{PHC}$, prescribed cardiovascular drugs and performed investigation during retrospectively for one year. The third and fourth study was based on a randomized, prospective, open-label study which was subsequently performed (III,IV). The study enrolled 160 patients with systolic HF who were randomized to either an intervention or a control group. The patients in the intervention group retrieved follow-up of HF qualified nurses and physicians in the PHC, involving education about HF and furthermore, optimizing the treatment according to guidelines if possible. The patients in the control group had a followup performed by their regular general practitioner (GP) receiving customary management according to local routines but there was no contact with HF nurses. The primary endpoint of the study was a composite endpoint consisting of changes in survival, hospitalization, heart function and quality of life (QoL) and to compare differences in resource utilization and costs (III,IV).

Results. In the first study, the prevalence was $2 \%$ and the average age was 78 years (I). The most frequent cause of HF was IHD followed o hypertension. The diagnosis in the study population was based on clinical criteria and only $31 \%$ had been subjected to echocardiography. The most common treatment was diuretics $(84 \%)$ and angiotensin converting enzyme inhibitors (ACEI) were used in $56 \%$ of patients. In the following prospective study, the intervention group had significant improvements in composite endpoints. There were in the intervention group more patients with reduced levels of NTproBNP $(\mathrm{p}=0.012)$ and improved cardiac function $(\mathrm{p}=0.03)$. No significant changes were found in New York Heart Association (NYHA) functional class or QoL. The intervention involved less health care contacts $(\mathrm{p}=0.04)$, less emergency ward visits $(\mathrm{p}=0.002)$ and hospitalizations $(\mathrm{p}=0.03)$. The total cost for HC and PHC was EUR 4471 in the intervention group and EUR 6638 in the control group which implies a cost reduction of EUR 2167 (33\%).

Conclusions. HF is common in PHC with a prevalence of $2 \%$ the study population had an average age of 78 years. Only $31 \%$ of the HF patients have performed an echocardiographic investigation. Treatment with ACEI occurred in $56 \%$. Differences were found between genders since women had performed significantly fewer echocardiographic investigations and, had less treatment with ACEI. When implementing HFMP in PHC, beneficial effects were found regarding cardiac function and health care-related costs in patients with systolic HF. These findings indicate that HFMP might be used even in PHC. 


\section{LIST OF PAPERS}

This thesis is based on four original articles which are listed beneath. The articles are numbered in Roman numerals which are used when the text are referred to the article in question.

I. Agvall B, Dahlström U. Patients in primary health care diagnosed and treated as heart failure, with special reference to gender differences. Scand J Prim Health Care. 2001;19:14-9.

II. Agvall B, Borgquist L, Foldevi M, Dahlström U. Cost of heart failure in Swedish primary healthcare. Scand J Prim Health Care. 2005;23:227-32.

III. Agvall B, Alehagen U, Dahlström U. The benefits of using a heart failure management programme in Swedish primary healthcare. Eur J Heart Fail. 2013;15:228-36.

IV. Agvall B, Paulsson T, Foldevi M, Dahlström U, Alehagen U. Resource use and cost implications of implementing a heart failure programme in Swedish Primary Health Care. Submitted in July 2013. 
ACE-I Angiotensin Converting Enzyme Inhibitor

$\mathrm{AF}$

Atrial fibrillation

AMI

Acute Myocardial Infarction

ARB

$\mathrm{BP}$

Angiotensin Receptor Blockers

BNP

Blood pressure

CE

Brain natriuretic peptide

CI

Clinical examination

COPD

Confidence Interval

CABG

Chronic Obstructive Pulmonary Disease

ECG

Coronary Artery Bypass Grafting

$\mathrm{EF}$

Electrocardiogram

ESC

EQ-5D

EUR

Ejection Fraction

GP

European Society of Cardiology

EuroQual 5D

Euro

ICD-10

General Practitioner

International Classification of Diseases and Related Health Problems $10^{\text {th }}$ version

IHD Ischemic Heart Disease

IQR Interquartile Range

$\mathrm{HC} \quad$ Hospital Care

HF Heart Failure

HFMP Heart Failure Management Programme

KCCQ Kansas City Cardiomyopathy Questionnaire

MRA Mineralocorticoid receptor antagonist

MLHF Minnesota Living with Heart Failure

NP Natriuretic Peptide

NT-proBNP N-terminal pro brain natriuretic peptide

NYHA class New York Heart Association Classification

PHC

RAS

QoL

SEK

SD

SF-36

Primary healthcare

Renin-Angiotensin system

Quality of Life

Swedish krona

Standard deviation

TLV

Short Form 36

Swedish Dental and Pharmaceutical Benefits Agency 


\section{INTRODUCTION}

It has been suggested that there is room for improvement regarding the management of heart failure (HF) patients in the primary healthcare (PHC), and there are indications that most of the research performed on HF patients has been based on hospitalised patients and the research concerning the management of HF in the PHC is sparse. HF patients arriving in the emergency ward of a hospital are generally suffering from a more unstable and severe form of $\mathrm{HF}$ while in the PHC the HF patients are usually in a more stable condition and usually have mild to moderate HF. Despite the latter situation of HF patients in the PHC, there is room for improvement regarding diagnostics, treatment and management.

\section{Background}

\section{Definition of heart failure}

There are many definitions of HF but a simplified definition is that there is a functional or structural impairment in the heart, reducing its ability to deliver oxygenated blood corresponding to the requirements of the metabolizing tissues of the body. In combination with reduced cardiac function a neuroendocrine activation occurs, including the ReninAngiotensin system (RAS). The haemodynamic consequences of these disturbances may explain symptoms (dyspnoea, fatigue) and findings (peripheral oedema) typical for HF. It is important to state that $\mathrm{HF}$ is not a disease but a clinical syndrome.

\section{Aetiology and comorbidity}

The most common causes of HF are ischemic heart disease (IHD) and hypertension, which explain about $80 \%$ of all cases of HF (1-5). Other causes are cardiomyopathies, valvular heart diseases and arrhythmias such as atrial fibrillation (AF), which explain the remaining $15-20 \%$ of cases.

There is a considerable comorbidity among HF patients such as IHD (59\%) and hypertension $(57 \%)$, while diabetes and chronic obstructive pulmonary disease (COPD) occur in approximately $25 \%$ of patients with $\mathrm{HF}$, and other conditions include anaemia and hypothyrosis $(6,7)$.

\section{Epidemiology}

The prevalence of HF is estimated to be about 2-3\%, which means that approximately 180,000 to 270,000 individuals in Sweden suffer from it $(5,8,9)$. A relatively large proportion of the population has reduced cardiac function without knowing it (10). The prevalence is approximately $1 \%$ in 40 -year-old individuals, and increases to $10 \%$ in individuals older than 75 years (5). The incidence of HF has declined during the past decade, probably due to improved management and modern treatment, which in large controlled studies have been shown to improve mortality as well as morbidity and quality of life (QoL) (11). The average age is approximately $75-83$ years for HF in a PHC-based population $(6,7,12)$. However, the mean age of the population has increased due to survival benefits, and that means that the number of patients living with HF has increased, since HF is more common in the elderly.

\section{Prognosis}

According to previous studies, HF is associated with a poor prognosis, and the one year mortality is approximately $20 \%$ while the 5 -year mortality is approximately $50-65 \%$ in population-based studies (13-15). HF has a higher mortality than many of the common 
malignancies (16). The long-term mortality after the first hospitalization for HF has decreased in Sweden during the past two decades (17).These results have been most apparent in younger patients, in men, and more for ischemic than for non-ischemic HF, but the mortality remains high, especially in patients in need of hospital care (HC). The annual mortality found in the Swedish HF registry is about $15 \%$ for hospital-based patients with symptomatic HF but only about $6 \%$ for HF patients managed in the PHC (18). This difference in mortality implies that HF patients in the PHC probably have a more stable and mild form of HF.

\section{Diagnostics of heart failure}

The diagnosis of HF is important but can be difficult in reality. In order to obtain the diagnosis of HF there are three criteria that have to be fulfilled. First of all, there must be symptoms that are typical of HF. Secondly, it is necessary to have clinical signs typical of HF and finally, it is necessary to verify impaired cardiac function. Even though these criteria are concrete and explicit, it can still be challenging to make the diagnosis properly.

\section{Symptoms and clinical signs}

When patients visit the PHC centre with symptoms such as shortness of breath, fatigue and weight gain, the suspicion of HF will arise. The most common clinical signs occurring in HF are peripheral oedema, dyspnoea at exertion, and pulmonary rales $(19,20)$. The diagnosis of $\mathrm{HF}$ can be difficult since symptoms and clinical findings typical of $\mathrm{HF}$ are non-specific and this is probably more apparent in the PHC (21-24). In particular, it is difficult to interpret symptoms in elderly patients with obesity or chronic lung disease (25-27). The symptoms have usually been bothering the patient for several weeks to months and have been insidious. The patients experiencing a rapid deterioration in HF, on the other hand, usually have more obvious symptoms which often result in an urgent visit to a hospital emergency ward and they are unlikely to appear in the PHC.

\section{Laboratory blood tests}

In cases when suspicion of HF arises, it is important to take blood samples. The routine blood tests recommended according to European guidelines are, haemoglobin, leukocytes, glucose, thyroid stimulating hormone, liver enzymes, creatinine and electrolytes. These recommended routine laboratory tests do not describe the heart function but are helpful in excluding other diseases which might also explain the symptoms.

\section{Natriuretic peptides}

The natriuretic peptides (NP) consist mainly of brain natriuretic peptide (BNP), which is the active ingredient, and N-terminal pro brain natriuretic peptide (NT-proBNP), whose function is so far unknown. The secretion of NP is increased when the cardiomyocytes are exposed to tension. NP is secreted mainly from the ventricles of the heart. BNP increases natriuresis, diuresis, and peripheral vasodilation and inhibits RAS $(28,29)$.

BNP and NT-proBNP are markers for HF with high sensitivity and specificity, which is useful in the PHC and the emergency ward when HF is suspected (30-33). An elevated level of NP implies that $\mathrm{HF}$ is likely, especially in an untreated patient. However, there are factors other than HF causing elevated levels of NP (34-36). When the cardiomyocytes are exposed to increased volumes, filling volumes, stiffness, ischemia and when there is decreased elimination, the levels of NP will increase. Factors which can elevate NP are atrial fibrillation (AF), pulmonary embolism, renal dysfunction, increasing age, unstable angina pectoris, acute myocardial infarction, valvular heart disease and moreover, women have slightly higher 
values than men (37-39). Factors which involve lower NP levels can be obesity and, more commonly, pharmaceutical treatment used in $\operatorname{HF}(27,40)$. Consequently, normal levels of BNP and NT-proBNP exclude HF in an untreated patient but elevated levels need to be investigated further with echocardiography (41).

There has been research to determine whether NP can be used to guide HF therapy $(42,43)$. Some studies have shown that monitoring of HF therapy with natriuretic peptides was successful (44-47). On the other hand, there are studies that have not achieved the same results (48-52).

NP is a strong prognostic predictor, whereas patients with higher levels of NP have a worse prognosis compared to patients with lower levels of NP (4,53-57).

\section{Electrocardiography}

Electrocardiography (ECG) is an important investigation in patients with $\mathrm{HF}$ since it can provide important information regarding damage to the myocardium, or if there is rhythm disturbances. A normal ECG means that the probability of HF is low in patients with acute HF $<2 \%$ and in chronic $\mathrm{HF}<10-14 \%(21,58-60)$.

\section{Chest X-ray}

When diagnosing HF, a chest X-ray is frequently conducted even though it provides little information about the cardiac function $(61,62)$. A chest X-ray can be normal even if the patient has impaired cardiac function. Even though the x-ray may show elements of stasis, pulmonary congestion or increased heart size, the cardiac function may be normal. The investigation is still useful but mainly to rule out other explanations, particularly diseases of the respiratory system (63).

\section{Cardiac function}

When diagnosing systolic HF, it is crucial to evaluate the cardiac function and confirm that there is impaired cardiac function. The clinical criteria (symptoms, clinical signs, ECG and chest X-ray) are not reliable when evaluating the cardiac function $(19,64)$. There are several methods to determine the cardiac function but the investigation that is most used and accessible is echocardiography (65-67). Echocardiography can be used to determine left ventricular function and estimate ejection fraction (EF). Moreover, it can detect structural changes such as cardiac hypertrophy, and visualize the wall motion and the valvular function.

\section{Treatment of Heart Failure}

When treating HF, there are different approaches. These include non-pharmacologic treatment, medications, and of course device treatment. The device treatment is strictly managed at departments of cardiology and not in the PHC and of that reason not further described. The main purpose of the treatment is to reduce symptoms, increase QoL, reduce hospital admissions and improve survival.

\section{Non-pharmacologic treatment}

Non-pharmacological treatment includes information of appropriate diets, salt and fluid intake and the importance of exercise in order to improve patient's skill and self-care behaviours. Most commonly, the information to the patient and their family is provided as a patient education so the patients understand the cause of HF and why symptoms occur. The education 
involves observing symptoms so the patient can recognize signs and symptoms of HF. The patients are advised to record their weight repeatedly and recognize weight gain. The patient receives information about self-care including knowledge when and how to reach health care provider and how to use flexible diuretic therapy when necessary. The non-pharmacological treatment involves understanding indications, dosing, effects and possible side-effects for each HF drug. Important components are also to understand the importance of following treatment recommendation, avoid excessive fluid consumption and to exercise regularly. It also includes the importance of smoking cessation, reducing alcohol consumption, and recommendations regarding vaccinations.

\section{Angiotensin-converting-enzyme inhibitor}

Treatment with angiotensin-converting enzyme inhibitors (ACEI) reduces morbidity and mortality and improves QoL in HF (68-71). Studies have shown that ACEI have the best effect when optimized doses are used (72). ACEI has a remarkable effect on the left ventricular remodelling, and is recommended in treatment of all HF patients.

\section{Angiotensin receptor blocker}

The effect of angiotensin receptor blockers (ARB) in HF is equivalent to ACEI. ARB is recommended when there are adverse reactions to ACEI (73-75). There are also studies that have shown that ARBs may be used in addition to ACEI in HF patients with EF <40\% (76).

\section{Beta blockers}

Beta blockers have been shown to reduce morbidity and mortality, and improve QoL (77-81). These are additional positive effects that occur even if the patient has previously been treated with ACEI or ARB. Beta blockers have an effect on left ventricular remodelling. In addition, they have an important role in treating IHD, which commonly occurs in HF. It has been shown that beta blockers reduce sudden cardiac death in HF $(77,78)$. Beta blockers are recommended in combination with ACEI or ARB in HF but should be given only to HF patients who are in a stable condition and should be used cautiously with a decompensated HF patient $(82,83)$.

\section{Mineralocorticoid receptor antagonists}

A drug that blocks aldosterone receptors is mineralocorticoid receptor antagonist (MRA), and this has a well-documented effect on survival and morbidity in patients with systolic HF $(84,85)$. MRA is recommended in treatment of HF patients who still have symptoms despite having already been treated with ACEI/ARB and beta blockers. It also has additional effect in patients with acute myocardial infarction (84). Although MRA has a good effect in HF there is a risk, particularly in elderly patients, of the development of impaired renal function with hyperkalaemia and hypotension. In the treatment there is reason to carefully monitor electrolytes and kidney function.

\section{Digoxin}

Digoxin has beneficial effects in HF regarding symptoms, QoL and physical function $(86,87)$. Digoxin increases the cardiac contractility and decreases the heart frequency, mainly due to blocking in the atrioventricular node. It is mainly used when there is a need to reduce the heart rate in $\mathrm{AF}$ and beta blockers are not tolerated. However, digoxin can be used to increase cardiac contractility in HF with sinus rhythm, but other treatments are preferred. 


\section{Diuretics}

Loop diuretics are useful in HF when there is fluid retention. The apparent advantage of loop diuretics is the rapid effect of increasing diuresis (88-90). The thiazides increase the diuresis but do not have the same rapid diuretic effect and therefore are more suited for HF combined with hypertension. Despite the evident effect of loop diuretics on diuresis and in reducing HF symptoms, there is no documentation on if diuretics affect morbidity or mortality.

\section{Heart failure in primary healthcare}

PHC in Sweden is organized by primary healthcare (PHC) centres in each county council. Each PHC center has team-based management, with general practitioners GPs collaborating with nurses, physiotherapists, occupational therapists, chiropodists, dieticians and sometimes psychological counsellors. There are usually nurses specializing in blood pressure, diabetes, asthma and COPD. There are also district nurses who see patients at PHC centres but who also carry out home visits. There are few PHC centres in Sweden that offer organized management of HF. When patients are diagnosed with HF, they are usually first admitted to hospital. After being stabilized and receiving treatment for HF, they are discharged from the hospital and referred to the PHC. If there is an HF clinic available at the hospital, the patients might have participated in a heart failure management programme (HFMP). Younger and male patients tend to continue their supervision and treatment at the hospital's outpatient clinic, but the elderly and women tend to be referred to the PHC (18). There are many patients diagnosed with $\mathrm{HF}$ in the PHC and consequently this has an important role in identifying $\mathrm{HF}$ (91). There are nevertheless shortcomings in the HF diagnostics, and the cardiac impairment is often not confirmed $(64,92,93)$.

The diagnosis of $\mathrm{HF}$ in the PHC has a relatively low sensitivity of $66 \%$ but diabetes and hypertension have a fairly high sensitivity of $83-89 \%$ (94). In the PHC there are in general nurse managements of diabetes and hypertension which probably affects the registration of these diagnoses. In the PHC, patients with $\mathrm{HF}$ are older, more often women and it is more common that they have hypertension and COPD, while IHD is more unusual in the PHC than in a hospital population $(18,25)$.

Patients with HF have several physician visits, irrespective of whether they are referred to the PHC for follow-up or if they have their continued outpatient follow-up at the hospital. A survey in Germany showed that patients have annually approximately six visits per year to their GP and 1.7 outpatient visits to an HC-based cardiologist (95). Studies in primary care show that a higher accessibility to a GP reduces the number of hospitalizations (96). Studies have shown that there is limited use in the PHC of medication recommended for HF, and when it is used, it is in in sub-optimal dosages $(7,97)$.

\section{Heart Failure Management Programme}

There are several studies reporting favourable results of an HFMP in reducing mortality and hospitalization $(98,99)$. These studies are mostly hospital-based and the interventions carried out by hospital-based personnel. The comparison of HFMPs is difficult since they are heterogeneous in terms of the models of care. The most common is that used by multiprofessional HF clinics but there are also HFMPs by telephone contact and others that are home-based or even in few cases PHC-based. Hospital-based studies have mainly enrolled patients when hospitalized due to HF and it can be assumed these patients had an unstable and 
more severe HF. The patients attending an HFMP at an HF clinic after being admitted have after one year better adherence to medication (100). A Swedish hospital-based study investigating the benefits of an HFMP showed that the intervention led to a reduction in mortality, and fewer hospital admissions and days in hospital (101). The intervention in this Swedish study was led by specially educated cardiac nurses and consisted of follow-up 2-3 weeks after discharge. At each visit, there was an evaluation of clinical status, supervision of the HF treatment, provision of individualized education about HF and social support to patients together with family. Furthermore, the HF clinic personnel were reachable by telephone if the patients' HF symptoms worsened. There was a similar intervention in the $\mathrm{COACH}$-study which did not show a reduction in mortality or hospitalization (102). In $\mathrm{COACH}$ study, the patients were randomized to a control group and a basic support or intensive support group. The control group had a follow-up by a cardiologist twice a year without involvement of the PHC, which can be considered as an advance follow-up and explain the outcome. However, the basic support group had as many as 13 outpatient visits (at hospital and home visits) after discharge and the intensive support group 25 outpatient visits (at hospital, in home visits and by telephone). It can therefore be assumed that the intervention itself is effective and not the frequency of the follow-up.

A Danish study compared HF patients discharged from hospital receiving an HFMP with extended follow-up period of 2.5 years by an HF clinic or having usual care in the PHC (103). The intervention involved follow-up with outpatient visits and telephone contact entailing symptom control, providing information of HF. Moreover, the patients had free access to nurses at the HF clinic. Both groups in this study had a high level of treatment concerning ACEI and beta blockers already at discharge and there were no benefits of long term followup at the HF clinic. A PHC-based German study consisting of follow-up by telephone and home visits with analogous intervention showed no improved health outcomes or healthcare utilization (104). However, at baseline there was already intense treatment with ACEI and beta blockers, giving little room for improvement. An Australian study comparing HFMP follow-up at an HF clinic with a home-based follow-up found there were lower healthcare costs due to fewer days of hospitalization (105). The patients were enrolled when hospitalized and randomized to either a follow-up consisting of outpatient HF clinic visits or home visits by a trained HF nurse. The intervention was the same in both groups and similar to the other mentioned studies. This difference might be caused of the accessibility to admissions when the patients were visiting the HC.

These studies all have a similar intervention programme consisting of a mixture of outpatient visits, home-based visits or telephone contact. The purpose should be to optimize the HF medication, offer adequate information about HF to increase the adherence regarding treatment and symptoms, self-care and symptom monitoring and flexible use of diuretics. The HFMP should also offer easy access to healthcare when HF worsens.

\section{Healthcare utilization of heart failure}

HF is a severe condition that consumes considerable healthcare resources, which implies that HF constitutes a major burden on healthcare economy (106). Previous studies have shown that the healthcare cost of $\mathrm{HF}$ is approximately $2 \%$ of the total national healthcare budget in developed countries (107-109). A Swedish study indicated that HF constituted a healthcare cost for Sweden of 3 billion SEK (107). This study used price tariffs from 1995 and patients were recruited from a hospital diagnose register covering all discharges and all bed-days for HF during 1995. The register in this study was probably insufficient concerning capturing data from $\mathrm{PHC}$ at that time since the recording of diagnoses in the $\mathrm{PHC}$ were not as rigorous 
and possible to apprehend. Consequently, the cost of hospital care dominated and was as high as $70 \%$ while the proportion of PHC was 6\%. In more recent Swedish studies the average cost per HF patient was EUR 5700-7610 $(110,111)$. A German study showed a yearly cost for HF of EUR 4681 per patient (95).

The COACH study was a comparison of basic support (intervention with nine visits to hospital and home visits) with intensive support (intervention involving 25 outpatient visits to hospital, home visits and telephone contact) which did not show a reduced cost (112). This study enrolled patients when they were hospitalized due to deteriorated HF. The explanation might be that there were intensive follow-ups in both groups. It is the hospitalization which in particular affects healthcare costs for HF (113). Almost 50\% of the patients that have recently been hospitalized for HF are re-admitted within six months, which has a profound effect on hospital resource utilization $(114,115)$. An intervention which can entail a reduction in hospital admissions and also a reduction in the number of days admitted to hospital would probably result in decreased healthcare costs. The number of days at hospital has previously been high, and in 1987 the average was 65 days at hospital per patient per year (116). Over the years, this number has declined markedly and in 1996 it was 10.7 days at hospital on average per year. More recent Swedish studies have shown a reduction in the number of days to 6.7 days in hospital $(110,111)$.

Patients with HF have a high utilization of PHC resources as well, but the results from various studies differ widely. A Swedish study showed that an HF patient in Sweden has 1.2 visits to GP (110). However, a German PHC-based study showed that a patient with HF had six visits to their GP. Meanwhile, in an English study, there were nine visits to the GP $(95,117)$. These divergent findings possibly illustrate that PHC differs in European countries and that these studies had somewhat different populations. 


\section{AIMS OF THE STUDY}

\section{General aim}

The general aim was to explore how patients with HF in a community area were diagnosed and treated, to calculate the healthcare costs and to elucidate if HF management with increased patient education of HF, accessibility to staff and intensified treatment of these patients could improve survival, hospitalization and healthcare costs.

\section{Specific aims}

- To describe patients diagnosed and treated for HF in a defined geographic area in primary healthcare in regard to factors such as diagnostic procedures, aetiologic diseases, and management, and to evaluate whether there was a difference between genders (I).

- To calculate the costs for patients with heart failure in a primary healthcare setting (II).

- To evaluate if the use of HFMPs also has beneficial effects on heart failure patients in primary healthcare in terms of improved cardiac function and QoL, reduced NTproBNP levels, and lower utilization of healthcare services and mortality (III).

- To evaluate resource utilization and the cost implications of implementing a heart failure management programme in primary healthcare (III).

\section{POPULATIONS AND METHODS}

This research is based on four articles where the data was obtained from various populations.

- Retrospective collection of data from 256 patients treated for symptomatic $\mathrm{HF}$ at a PHC centre with a total population of 12,400 inhabitants. (I).

- Retrospectively retrieved data from 115 patients diagnosed with HF in two PHC centres with a total population of 19,400 inhabitants (II).

- Prospective randomized open-label study of 160 patients with systolic heart failure in five different PHC centres (III,IV).

\section{Population (I)}

The study was performed in the Åtvidaberg community located in south-eastern Sweden, with a population of 12,400 inhabitants. In the community, there were two PHC centres. There was one PHC centre with five GPs who supported approximately 10,000 inhabitants, and one PHC centre with a single GP who supported approximately 2400 inhabitants. Both of these PHC centres had computerized medical record documentation.

\section{Inclusion criteria}

Patients with a diagnosis of HF or being treated for HF, living in the Åtvidaberg community.

\section{Exclusion criteria}

Patients were excluded if the diagnosis of HF was evidently incorrect and was revoked according to medical record documentation. 


\section{Population (II)}

The study included 115 patients diagnosed with heart failure at two PHC centres in southeastern Sweden, one in Åtvidaberg community and one PHC centre in Linköping community, with a total population of 19,400 people. These PHC centres had computerized health record documentation. The patients were included during the time period from 1999 to 2000.

\section{Inclusion criteria}

Patients diagnosed with HF (I50 and I42) according to ICD-10 coding in the PHC centre medical healthcare record documentation were included.

\section{Exclusion criteria}

Patients with dementia, malignancy or suspected malignancy were excluded from the study.

\section{Population (III,IV)}

The study included 160 patients with systolic HF from five PHC centres in south-eastern Sweden. These PHC centres were located in Vimmerby, Åtvidaberg and Linköping community.

\section{Inclusion criteria}

Patients with systolic HF, defined as an EF $<50 \%$, and who were $>18$ years of age with New York Heart Association (NYHA) functional class I-IV were included in the study. All patients had met the European Society of Cardiology (ESC) clinical practice guidelines diagnostic criteria in order to be in the study.

\section{Exclusion criteria}

Patients excluded from the study were those with a normal EF, haemodynamically unstable patients on the waiting list for cardiac surgery (cardiac transplantation, revascularization, or heart valve surgery), patients with an acute myocardial infarction (AMI) within three months, patients with impaired renal (serum creatinine $>250$ mikromol/L) or liver function (liver enzymes more than three times the normal value), patients with severe COPD (treated continuously with oral steroids and/or oxygen treatment), patients with diseases with an expected survival of less than one year, and patients unable to give informed consent due to diminished cognitive function (caused by dementia or cerebrovascular insult) or participating in another trial.

\section{Methods (I)}

This was a descriptive retrospective study in which medical health records of all patients with diagnoses of HF, hypertension, IHD, history of previous AMI or AF were examined in order to find all patients treated for HF. All the medical healthcare records in the PHC centres and the nearby hospital were carefully scrutinized. Data was documented regarding age, gender, concomitant diseases, how the diagnosis of HF was verified, and current treatment. The NYHA class for each patient was evaluated based on the medical healthcare record documentation and the extent of the medication. The concomitant diseases recorded were 
IHD, history of AMI, diabetes mellitus, dilated cardiomyopathy, valvular heart disease, COPD and AF. The diagnosis process was reviewed and separated into four different investigation categories: 1) clinical examination (CE), 2) CE with an ECG, 3) chest x-ray and 4) echocardiography. The pharmaceutical treatments were separated into digitalis, diuretics and ACEI. Treatment with ACEI was further scrutinized regarding the treatment dose of the ACEI which was recorded and categorized in three different dosage levels. In order to compare these drugs, a percentage of dose level for each drug was calculated. A dosage level that was $100 \%$ signified a daily treatment with captopril $100 \mathrm{mg}$, ramipril $10 \mathrm{mg}$, enalapril and lisinopril $20 \mathrm{mg}$. according to local guidelines at that time. No other ACE inhibitor was used and the use of ARBs was negligible.

\section{Methods (II)}

\section{Data collection}

When accepted for the study, all patients were given an echocardiographic examination to assess their cardiac function. The computerized healthcare records in the PHC centres and the $\mathrm{HC}$ were carefully scrutinized retrospectively for one year before the date the patient was included in the study. The patient's age, gender, NYHA class and concomitant diseases were collected. The number of visits to the GP, nurses, occupational therapist, physiotherapist and chiropodist in the PHC were also registered. The nurses serving in the PHC centres are assigned different tasks and were therefore categorized as regular PHC nurses, specialized PHC nurses (hypertension, diabetes and asthma/COPD nurse) and district nurses. The medical healthcare records from the Department of Cardiology, Internal Medicine, Surgery and Orthopaedics were reviewed and the number of days in hospital and number of visits to physicians and specialized nurses at the hospital were collected. All X-rays (such as chest Xrays, coronary angiography, skeletal X-ray and computed tomography scanning) and physiological investigations (such as echocardiography, ultrasound of blood vessels, scintigraphies and exercise tests) conducted during the study period according to the PHC and HC medical healthcare records were retrieved. In the same way, data on the medication that was prescribed during the study period were retrieved. The dosages and number of days on treatment were registered. The use of medications was separated into medication for cardiovascular diseases (beta blockers, calcium inhibitors, ACE inhibitors, Angiotensin II inhibitors, digoxin, diuretics, and statins), diabetes and COPD.

\section{Resource utilization}

From the collected data, the patient's average number of days hospitalized (inpatient care), and visits to physicians and nurses (outpatient care) at $\mathrm{HC}$ was calculated. The average number of visits to a GP, nurses, district nurses and paramedical staff in the PHC as well as the average number of days at a nursing home was calculated. The price list for PHC was retrieved from the Ödeshög study to allow calculation of the patient costs (118). The prices representing inpatient and outpatient care for $\mathrm{HC}$ were retrieved from the County Council of Östergötland's price tariffs for healthcare utilization for 2003. The costs for HC and PHC used are presented in Table I. 
Table I. Cost per different unit of healthcare resources.

\begin{tabular}{lr}
\hline Unit & SEK/unit \\
\hline & \\
Hospital care & \\
Inpatient care & 6200 \\
Stay/day in an intensive care unit & 3300 \\
Stay/day in a hospital ward & \\
Outpatient care & 2459 \\
Visit to a physician & 930 \\
Visit to a heart failure nurse & \\
& \\
Primary healthcare & \\
Cost related to general practitioner & \\
Visit & 1047 \\
Home visit & 14 \\
Telephone contact & 16 \\
Prescription of drugs & \\
Cost related to nurses & 202 \\
Visit (regular nurse) & 438 \\
Visit to an asthma nurse & 415 \\
Visit to a diabetic nurse & 300 \\
Visit to a hypertension nurse & \\
Cost related to district nurse & 211 \\
Visit & 299 \\
Home visit & \\
Cost related to paramedical staff & 509 \\
Occupational therapist & 257 \\
Physiotherapist & 410 \\
Chiropodist & \\
Costs related to other resources & \\
Stay/day in a nursing home & 417 \\
\hline
\end{tabular}

$\mathrm{SEK}=$ Swedish kronor.

The price lists for X-ray and physiological examinations were derived from the Departments of Radiology and Clinical Physiology. The cost of medication was based on the Swedish Dental and Pharmaceutical Benefits Agency (TLV) price list for 2003.

The costs were calculated as mean and median values for each patient. These were summarized in total but also subdivided to show PHC, HC, pharmaceutical and examination costs. All the costs were calculated and presented in Swedish krona (SEK).

The baseline characteristics and the cost calculation were presented in total, normal systolic cardiac function and impaired systolic function (according to the echocardiography performed at inclusion of the study). Patients with $\mathrm{EF}<50 \%$ were considered to have a reduced systolic cardiac function and patients with $\mathrm{EF}>50 \%$ were perceived as having normal systolic cardiac function.

\section{Method (III,IV)}

The study was prospective, randomized open-label and the study period was one year. All patients with HF were initially subjected to echocardiography and patients that met the inclusion criteria and none of the exclusion criteria were enrolled in the study. 


\section{Stratification}

In order to avoid a skewed distribution between study arms, there was a stratification based on age ( $\geq 80$ or $<80$ years of age) and treatment of furosemide ( $>80$ or $\leq 80 \mathrm{mg}$ per day).

Randomization of patients was in 12 blocks within each PHC centre and randomization carried out in the main centre before patient was included in the study. All information about the randomization was enclosed in a sealed envelope which was opened when randomization was pursued.

\section{The intervention}

At each PHC centre, there was an HF-trained nurse along with GPs interested in HF, who was responsible for the intervention. These nurses were educated about HF disease and were also educated regarding management and monitoring of HF medication. The HF nurses were therefore capable of optimizing the HF medication and of offering adequate information about HF in order to increase the patient's adherence to treatment, self-care, symptom monitoring and flexible use of diuretics. The patients had open direct access to the HF nurses at the PHC centre when experiencing worsening HF. An alliance between the HF nurses in the PHC centres and nurses at the special HF clinics in hospitals was established to allow consultation and support in complex situations.

When the patients were randomized to the intervention group, they had an initial consultation with the GP, followed by a visit to an HF-educated nurse. The HF nurses presented oral and written information about $\mathrm{HF}$ and also information from a validated computer-based information programme (119). There was an overview of each patient's medication and clinical status in order to optimize the medication. The HF nurses had a mandatory follow-up examination within six weeks with the objective to ensure that medical treatment was optimized according to recognized guidelines. The HF nurse contacted the patients by telephone within one month and after six months to ensure the patients had maintained their status and adherence to their HF medication. Additional contacts were scheduled only if the patient had a clinical need. The basic treatment with ACEI or ARB and beta blockers was introduced if missing, and was optimized. For patients having adverse reactions to the medication, such as hypotension, renal dysfunction or bradycardia, a reduction in dosage and suboptimal treatment doses were accepted. MRA or an ARB was added if the patient still had symptomatic HF after this basic treatment.

\section{The study process}

A flow chart illustrating the study process is presented in Figure 1. Before entering the study, all patients were given an echocardiographic examination in order to verify a systolic dysfunction. The patients had a visit at inclusion to a physician and an HF nurse, and were randomized to either the intervention or control group. The physician-based NYHA functional class, physical examination, and quality of life (QoL) were assessed and blood samples for routine laboratory analyses and NT-proBNP were obtained. All patients included in the study had been given a chest X-ray. The patients randomized to the intervention group participated in the intervention while the patients in the control group were managed by their ordinary GP according to clinical routines.

The length of the follow-up period was 12 months for all participants. At the end of the study period all patients made a final visit to a physician and all examinations performed at the start of the study were repeated, with the exception of the chest X-ray. 
Figure 1. Illustrates the study design.

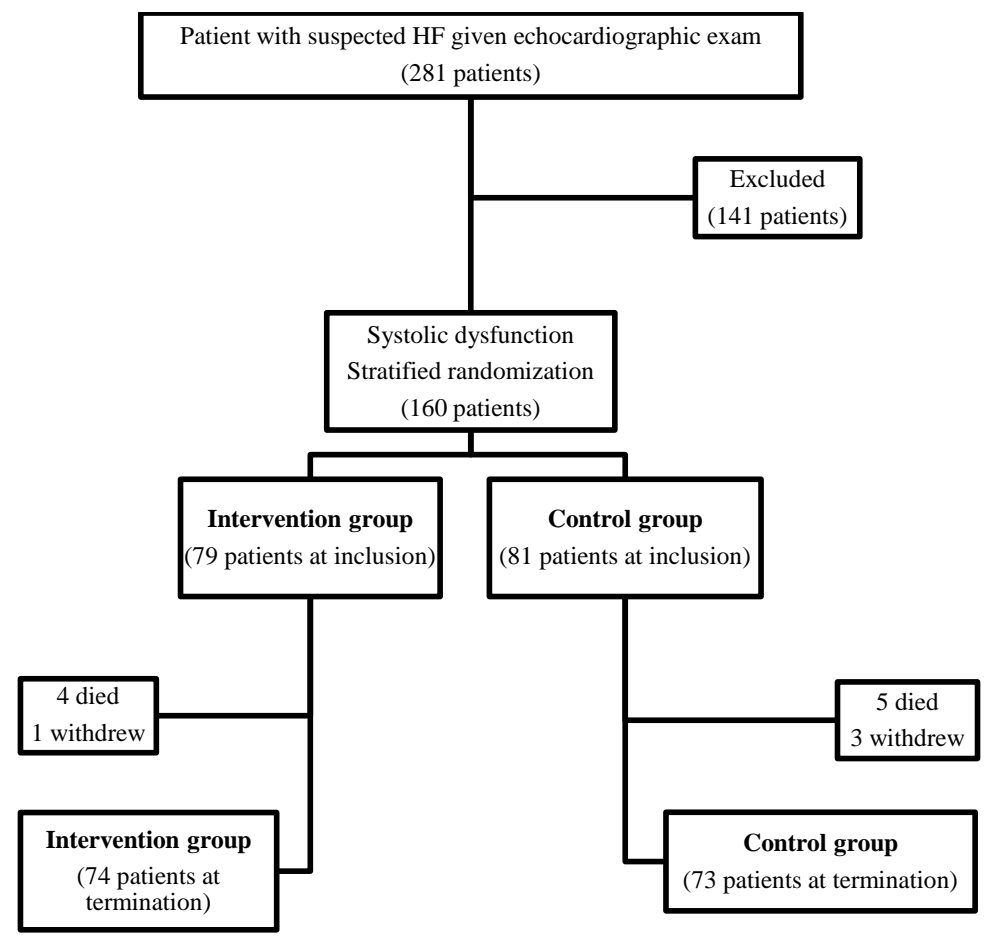

\section{Echocardiography}

The Doppler echocardiographic examinations (Vingmed System Five) were carried out with the patient lying in a left lateral position, and both M-mode and 2D methodology were applied in the examination. Semi-quantitative levels were applied when defining the systolic left ventricular function. The left ventricular function was normal when $\mathrm{EF} \geq 50 \%$, a mild systolic dysfunction was EF 40-49\%, a moderate dysfunction EF 30-39\%, and a severe dysfunction of the systolic left ventricular function signified an $\mathrm{EF}<30 \%$. This method has been validated against the modified Simpson algorithm $(120,121)$.

\section{Blood sampling and NT-proBNP measurement}

Blood sampling was conducted after the patient had been resting for 30 minutes. The samples were collected in pre-chilled plastic tubes containing EDTA (Terumo EDTA K-3), and then preserved in ice and centrifuged at $3000 \mathrm{~g}$ for 10 minutes at a temperature of $+4{ }^{\circ}$ Celsius. The samples were subsequently immediately frozen and deposited at a temperature of -70 until subsequent analysis. No sample was thawed and liquefied before analysis. NT-proBNP was analysed by using an electrochemiluminescence immunoassay (Elecsys 2010, Roche Diagnostics, Mannheim, Germany), a method that had previously been validated (122). The total coefficient of variation was $4.8 \%$ at the level of $217 \mathrm{ng} / \mathrm{L}$ and $2.1 \%$ at the level of 4261 $\mathrm{ng} / \mathrm{L}$ in our laboratory. 


\section{Measurements of quality of life and functional capacity}

Quality of life (QoL) was evaluated with the SF-36 which is a validated QoL instrument (123). The evaluation of SF 36 was self-assessed by the patients. SF-36 evaluates eight different dimensions: physical function (PF), role physical (RP), body pain (BP), general health $(\mathrm{GH})$, vitality (VT), social function (SF), role emotional (RE), and mental health $(\mathrm{MH})$.

The NYHA classification was used to evaluate the functional capacity. NYHA is separated into four functional levels. The patients in NYHA class I have no HF symptoms, in NYHA class II there are HF symptoms during physical exertion, in NYHA class III there is a restricted life with HF symptoms even with minor effort and in NYHA class IV there are HF symptoms even at rest.

\section{Evaluation of composite endpoints}

Composite endpoints were valued by using a score system from a previous study (125). A composite endpoint was assessed from the changes in survival, hospitalization, heart function and QoL which is illustrated in Table II. The survival was based on the mortality versus survival at the end of the study, and the hospitalization was based on the first hospitalization for cardiovascular disease. The heart functions were based on EF at echocardiography and NT-proBNP which could be improved, unchanged or worsened. The QoL was based on a physical component scale and a mental component scale.

Table II. The allocation of scores for evaluation of composite endpoints.

\begin{tabular}{lc}
\hline End Point & Score \\
\hline & \\
Survival & \\
Death (at any time during the trial) & -3 \\
Survival to the end of the trial & \\
Hospitalization & -1 \\
First hospitalization for cardiovascular disease & 0 \\
No hospitalization & \\
Heart Function & \\
Echocardiography & +1 \\
Improved EF & 0 \\
Unchanged EF & -1 \\
Worsened EF & \\
NT-proBNP & +2 \\
Decreased $\geq 500$ & +1 \\
Decreased <500 & 0 \\
Unchanged & -1 \\
Increased <500 & -2 \\
Increased $\geq 500$ & \\
Quality of Life/SF 36 & \\
Physical Component Scale and Mental Component Scale & +2 \\
Increased $\geq 5$ & +1 \\
Increased 1-4 & 0 \\
Unchanged & -1 \\
Decreased 1-4 & -2 \\
Decreased $\geq 5$ & -11 to +8 \\
Possible score & \\
\hline &
\end{tabular}

Note; EF, ejection fraction; NT-proBNP, N-terminal pro brain natriuretic peptide; SF-36, Short Form 36. 


\section{Assessed resource utilization}

During the study period all healthcare contacts with $\mathrm{HC}$ and PHC were registered. This record included the number of visits to physicians, various nurses, and paramedical personnel. The number of inpatient days of hospitalization in Department of Internal Medicine or Geriatric was also recorded. The unit costs for 2012 are illustrated in Table III. Admissions, inpatient days in the Department of Neurology, Orthopaedics, Surgery and other surgery were not recorded since such care was considered to have little relation to heart disease. There was a separate registration of nurse visits, which included cardiovascular and haemodynamic monitoring during the initial six weeks of the study period. These cardiovascular nurse visits were summarized, whereas other visits to nurses that did not include haemodynamic monitoring were excluded. Investigations such as chest X-ray, coronary angiography, echocardiography, and physiological tests were also collected. Unit costs were derived from the County Council of Östergötland's price tariffs for healthcare utilization for 2012. These tariffs for healthcare utilization are applied in the south-eastern region of Sweden and have been used to estimate patient costs in $\mathrm{HC}$ and PHC in the present study.

Table III. Official prices for each cost item in South-East of Sweden in 2012.

\begin{tabular}{lr} 
& Price (EUR) \\
\hline Hospital Care & \\
Inpatient care & 724 \\
Stay/day in hospital ward & \\
Outpatient care & 535 \\
Emergency ward & 377 \\
Visit to physician & 143 \\
Visit to a heart failure nurse & \\
& \\
Primary Healthcare & 220 \\
Cost related to general practitioner & 36 \\
Visit & \\
Administrative (prescription/telephone) & 74 \\
Cost related to nurses & \\
Visit to specialized nurse & 74 \\
Cost related to district nurse & 74 \\
Visit & \\
Home visit & 91 \\
Cost related to paramedical staff & \\
Paramedicine &
\end{tabular}

EUR 1 = SEK 8.7

The ongoing medication, dosages, and number of days on treatment were registered according to HC and PHC medical health records. Compilation of the treatment was conducted to explore how many patients were treated with RAS blockade and beta blockers at entry and at the end of the study. There were also calculations of the percentage average dosage of the recommended optimal dosage for RAS blockade and beta blockers. In order to compare the dosage of the ACEI, ARB and beta-blockers, a percentage of the recommended dosages were calculated. These recommended dosages for these medications were those according to local routine recommendations. The dosages which were considered as $100 \%$ of recommended dosage for ACEI was captopril $100 \mathrm{mg} /$ day, enalapril $20 \mathrm{mg} /$ day, ramipril $10 \mathrm{mg} /$ day and lisinopril $20 \mathrm{mg} /$ day. For ARB, the recommended dosages was candesartan $32 \mathrm{mg} / \mathrm{day}$, losartan $100 \mathrm{mg} /$ day, valsartan $160 \mathrm{mg} /$ day and for beta-blockers the dosages considered as 
$100 \%$ were bisoprolol $10 \mathrm{mg} /$ day, metoprolol $200 \mathrm{mg} /$ day, carvedilol $50 \mathrm{mg} /$ day and atenolol $100 \mathrm{mg} /$ day.

The cost of medication was based on the Swedish Dental and Pharmaceutical Benefits Agency (TLV) price list for 2012. The price tariffs were converted from Swedish kronor (SEK) to Euro EUR. The exchange rate was calculated from the average value of the EUR for the year 2012 (Exchange rate: 1 EUR = SEK 8.7).

\section{Statistics}

Continuous variables are presented as mean $\pm \mathrm{SD}$ and median (interquartile range (IQR)) for baseline measures and as mean $\pm \mathrm{SD}$ for costs, since the average cost is the key statistic for economic outcomes (I-IV). Differences in the distribution of continuous variables between intervention groups were tested using the nonparametric Mann-Whitney U-test, whereas the chi-squared test was used for discrete variables (I-IV). A multiple regression analysis was carried out to exclude the possibility that the variables of gender, age, NYHA class, cardiovascular diseases, and cardiac function had affected the cost (II). The analysis of NTproBNP at baseline and the end of the study between the intervention group and the control group involved the use of three different tests using both T-tests between groups of both untransformed as well transformed variables of the difference between inclusion and termination plasma concentration of NT-proBNP, and also by use of the Mann-Whitney U test (III).

The p-value under the null hypothesis of no difference in total cost between intervention groups was the primary test of the intervention's impact on the total cost of healthcare (IV). To explore the strength of the outcome, two sensitivity analyses were performed. One was a comparison of total healthcare costs adjusted for potential differences in baseline characteristics between groups (IV). The other was a comparison of healthcare costs accounting for potential differences in follow-up time between groups. For these, log-normal regression models were used with adjustment for age, sex, ischemic heart disease, hypertension, diabetes mellitus, chronic obstructive pulmonary disease, NYHA functional class, heart rate, systolic and diastolic blood pressure, and creatinine values encountered at baseline (125). The second model also included time in study as an offset term. Continuous variables were modelled as psplines with four degrees of freedom (126). Model fit was assessed by normal qq-plots of the residuals. Inference was based on the p-value for the intervention-group coefficient. A p-value of less than 0.05 was regarded as a statistically significant difference.

The statistical analyses were carried out using three different and commercially available statistical software package programs. The commercial statistical software program StatView (SAS Institute Inc.) was used in paper I while SPSS v 15.0 (IBM SPSS Statistics) was used in paper II. The statistical processing of papers III and IV was conducted with the assistance of the commercially available statistical software-package Statistica v. 10.0 (Statsoft Inc., Tulsa, OK USA) (III,IV).

\section{Ethics}

The Ethics Committee at the University Hospital of Linköping approved the study. 


\section{RESULTS}

\section{Result I}

\section{Distribution of age}

In the initial descriptive retrospective study there were 256 patients with a diagnosis of HF. The average age was 78 years in total, and the average age for women was 80 years and for men 76 years $(\mathrm{p}<0.05)$. The age distribution is described in Figure 2.

Figure 2. Age distribution, totally and divided by sex.



\section{Etiological factors and concomitant diseases}

IHD was the most common aetiology, followed by hypertension, which is illustrated in Table IV (I). Compared to women, men had IHD significantly more often $(\mathrm{p}<0.05)$.

Table IV. Etiological factors, chronic diseases associated with HF and NYHA functional classes totally and divided by sex.

\begin{tabular}{llllllll}
\hline \multicolumn{1}{c}{ Chronic diseases } & $\mathrm{n}$ & $\begin{array}{c}\text { Total } \\
(\%)\end{array}$ & $\mathrm{n}$ & $\begin{array}{c}\text { Women } \\
(\%)\end{array}$ & $\mathrm{n}$ & $\begin{array}{c}\text { Men } \\
(\%)\end{array}$ & p-value \\
\hline Aetiology of HF (main reason) & & & & & & & \\
$\quad$ IHD & 142 & $(55)$ & 50 & $(46)$ & 92 & $(62)$ & $<0.05$ \\
$\quad$ Hypertension & 46 & $(18)$ & 23 & $(21)$ & 23 & $(16)$ & NS \\
$\quad$ VOC & 6 & $(2)$ & 2 & $(2)$ & 4 & $(3)$ & NS \\
$\quad$ Unknown & 62 & $(24)$ & 33 & $(31)$ & 29 & $(19)$ & NS \\
Chronic diseases associated with HF & & & & & & & NS \\
$\quad$ Diabetes mellitus & 64 & $(25)$ & 23 & $(21)$ & 41 & $(28)$ & NS \\
$\quad$ Chronic obstructive lung disease & 35 & $(14)$ & 13 & $(12)$ & 22 & $(15)$ & NS \\
$\quad$ Atrial fibrillation & 97 & $(38)$ & 43 & $(40)$ & 54 & $(37)$ & NS \\
NYHA functional class & & & & & & & \\
$\quad$ I & 44 & $(17)$ & 20 & $(20)$ & 22 & $(15)$ & NS \\
$\quad$ II & 130 & $(51)$ & 48 & $(48)$ & 78 & $(53)$ & NS \\
$\quad$ III & 78 & $(30)$ & 30 & $(30)$ & 46 & $(31)$ & NS \\
IV & 4 & $(2)$ & 2 & $(2)$ & 2 & $(1)$ & NS \\
\hline
\end{tabular}

A history of AMI occurred in $40 \%$ of all the patients and there was a significant difference between genders, whereas $49 \%$ of the men and $27 \%$ of the women had had AMI ( $<<0.001)$. 


\section{Diagnostics of heart failure in primary healthcare}

The diagnosis of HF was based on clinical criteria in $69 \%$ of the patients. Consequently it was found that $31 \%$ had undergone echocardiographic examination according to recommendations. The distribution regarding how the diagnosis of HF was determined is illustrated in Figure 3. There was a significant difference between genders since $20 \%$ of the women and $38 \%$ of the men had been subjected to echocardiographic examination $(\mathrm{p}<0.01)$.

Figure 3. Diagnostic procedures used in the whole study population and divided by gender. The first group (CE) had diagnosis of heart failure based on a clinical examination (CE) and the second group (CE+ECG) also had an ECG in addition to the CE. The third group (X) had a CE, ECG and chest X-ray, and the fourth group had an echocardiographic investigation.

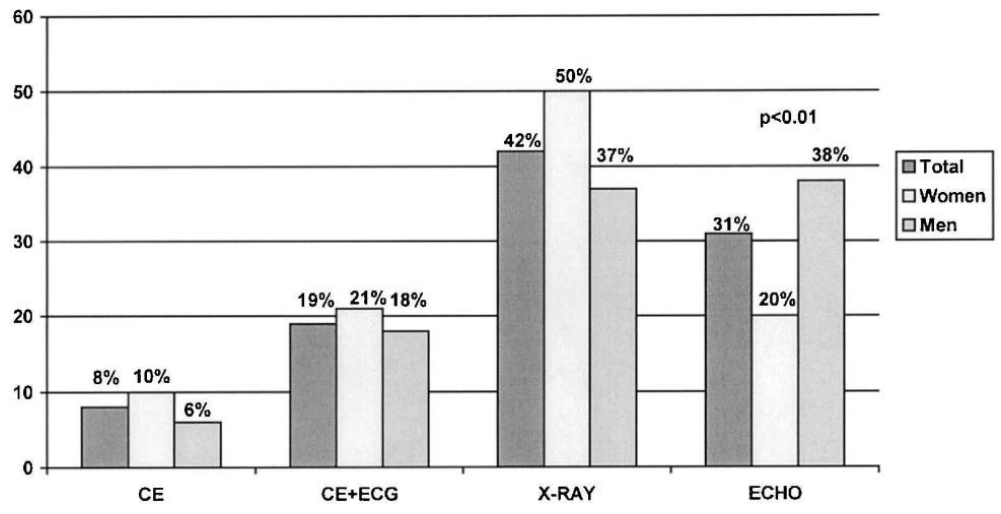

\section{Treatment of heart failure in primary healthcare}

Treatment with diuretics had been given to $84 \%$ of the patients. ACEI was used in $56 \%$ and $40 \%$ of the patients had been treated with digoxin. There was no significant difference between the genders regarding treatment with diuretics and digitalis. However, there was a significant difference between the genders in treatment with ACEI, in which $64 \%$ of the men had an ACEI compared to $43 \%$ of the women $(\mathrm{p}<0.01)$. It was found that $52 \%$ of the patients treated with ACEI had an optimized dosage.

\section{Results II}

There were 294 patients with the diagnosis of HF (I50, according to the ICD-10 classification), and they were identified from the computerized healthcare records in the PHC centres. The patients not fulfilling the inclusion criteria were excluded and the remaining 174 were offered the opportunity to participate. Fifty-nine patients declined to participate mainly due to high age, declining health and cognitive impairment. Finally, 115 consecutive patients with a clinical diagnosis of HF were included. Of these, $52(45 \%)$ were women and $63(55 \%)$ were men. The average age was 77 (SD 8) years. The women had a mean age of 78 (SD 8) years and for the men it was 76 (SD 8). 


\section{Cardiac function according to echocardiography}

There were 33 patients with HF diagnosis who had normal cardiac function, verified with echocardiography, and there were 82 patients with impaired cardiac function. Among the patients with impaired cardiac function, there were $26(32 \%)$ with a mild systolic dysfunction, $41(50 \%)$ with a moderate dysfunction, $10(12 \%)$ with a severe dysfunction, and there were also five patients $(6 \%)$ with a diastolic dysfunction.

\section{Comorbidity in patients with $\mathrm{HF}$ in the PHC}

The most common concomitant diseases in the patients who participated in this study were IHD and hypertension. There was a higher occurrence of IHD (83\% versus 52\%) among the patients with cardiac dysfunction. Among patients with impaired cardiac function there were more with a previous history of AMI, and coronary artery bypass grafting (CABG) surgery compared to patients with a normal cardiac function. However, there was no difference in the prevalence of diabetes mellitus, valvular heart disease and COPD between these groups.

\section{The pharmacological treatment of heart failure}

There was no significant difference in drug treatment regardless of cardiac function. The patients with a normal cardiac function had a higher proportion of beta blocker and diuretic use but a slightly lower proportion of ACEI and warfarin therapy. There were no differences in treatment in regard to calcium channel blockers, digitalis, statins, long-acting nitrates and antiplatelet agents.

\section{The resource utilization for patients with heart failure}

The average cost of a patient with the diagnosis of HF in the Swedish PHC was SEK 37,100 (median SEK 23,283) regardless of cardiac function or gender. The distribution of costs is illustrated in Table $\mathrm{V}$. The distribution of costs in percentage showed that the most costly entity was the $\mathrm{HC}(47 \%)$. PHC was responsible for $22 \%$ of the costs, medication for $18 \%$, nursing home for 5\%, and X-rays and physiological examinations for $6 \%$.

On average, there were 4.3 days at hospital during the study period and there were 0.7 visits to physicians and 0.1 visits to the specialist nurse in HC. There were on average 4.6 visits to the GP in the PHC and a total of 8.5 visits to the district nurse, and 0.2 to 1.0 visits to specialized nurses in PHCs.

\section{Results (III,IV)}

\section{Baseline characteristics}

There were 301 patients with suspected HF who were given echocardiography, and 141 patients did not meet the inclusion criteria. In total, 160 patients were included in the study and the mean age was 75 years (SD 7.8). Four patients died in the intervention group and five patients died in the control group. The overall mortality was $6 \%$.

In the baseline characteristics, there was no significant difference in follow-up time in the study, haemodynamics, NYHA-classes, renal function, concomitant diseases or medication, which is illustrated in Table V. 
Table V. Baseline characteristics of the patients included in the two treatment groups in the study.

\begin{tabular}{|c|c|c|}
\hline & Intervention Group & Control Group \\
\hline Number of patients, $\mathrm{n}(\%)$ & 79 (49) & $81(51)$ \\
\hline Mean age, years (SD) & $75(8.6)$ & $75(7.1)$ \\
\hline Age, median (IQR) & $76.0(74.0-80.0)$ & $76.0(69.5-80.0)$ \\
\hline \multicolumn{3}{|l|}{ Gender } \\
\hline Women, n (\%) & $21(27)$ & $28(36)$ \\
\hline Men, n $(\%)$ & $58(73)$ & $53(64)$ \\
\hline \multicolumn{3}{|l|}{ Follow-up } \\
\hline Time in study, days, mean (SD) & $379(38.1)$ & $374(45.8)$ \\
\hline Time in study, days, median (IQR) & $378(360-413)$ & $377(364-392)$ \\
\hline Number of deaths, $\mathrm{n}(\%)$ & $4(6)$ & $5(7)$ \\
\hline Number of drop outs, $\mathrm{n}(\%)$ & $1(1)$ & $3(4)$ \\
\hline \multicolumn{3}{|l|}{ Haemodynamics } \\
\hline Heart rate, mean bpm (SD) & $70(14)$ & $70(11.6)$ \\
\hline Heart rate, median (IQR) & $70(60-77)$ & $70(58.5-77.5)$ \\
\hline Systolic BP, mean mm Hg (SD) * & $131(19)$ & $134(22.2)$ \\
\hline Systolic BP, median (IQR) & $135(115-148)$ & $130(120-140)$ \\
\hline Diastolic BP, mean mm Hg (SD) & $71(10.8)$ & $73(12)$ \\
\hline Diastolic BP, median (IQR) & $72(66-80)$ & $75(68-80)$ \\
\hline \multicolumn{3}{|l|}{ Renal function } \\
\hline S-creatinine mean umol/L (SD) & $110.5(30.7)$ & $111.4(31.8)$ \\
\hline S-creatinine median umol/L (IQR) & $103(87-128)$ & $102(91.5-118)$ \\
\hline \multicolumn{3}{|l|}{ Concomitant diseases } \\
\hline IHD, n (\%) & $64(81)$ & $69(85)$ \\
\hline Hypertension, n (\%) & $33(42)$ & $27(33)$ \\
\hline Diabetes, n (\%) & $17(22)$ & $26(32)$ \\
\hline COPD, n $(\%)$ & $15(19)$ & $16(20)$ \\
\hline \multicolumn{3}{|l|}{ Medication } \\
\hline RAS-blockade, n(\%) & $62(78)$ & $67(83)$ \\
\hline Beta blockers, $\mathrm{n}(\%)$ & $54(68)$ & $61(75)$ \\
\hline MRA, $\mathrm{n}(\%)$ & $14(18)$ & $10(12)$ \\
\hline Furosemide, n $(\%)$ & $55(70)$ & $51(63)$ \\
\hline Digoxin, $\mathrm{n}(\%)$ & $17(22)$ & $21(26)$ \\
\hline
\end{tabular}

Note: n: numbers; SD: standard deviation; bpm: beats per minute; BP: blood pressure; IHD: ischemic heart disease; COPD: chronic obstructive pulmonary disease; NYHA: New York Heart Association functional class RAS-blockade: renin-angiotensin-system blockade. MRA: mineralocorticoid receptor antagonists

* There was missing data for one patient in the intervention group for systolic blood pressure

\section{Medication}

When entering the study, $78 \%$ of the patients were being treated with RAS-blockade in the intervention group and $83 \%$ in the control group ( $\mathrm{p}=0.50)$. At the end of the study, $100 \%$ of the patients were receiving RAS-blockade in the intervention group and in the control group it 
was $84 \%(\mathrm{p}=0.002)$. The average dosage level (percentage average dosage of the optimal dosage) of RAS blockade was $63 \%$ at baseline in both groups. At the end of the study, the average dosage level of RAS-blockade was $94 \%$ in the intervention group and $69 \%$ in the control group ( $\mathrm{p}<0.0001$ ). The same calculation was made for beta blockers, showing that $68 \%$ of patients in the intervention group had treatment with beta blockers and $75 \%$ in the control group ( $\mathrm{p}=0.33$ ). There were $73 \%$ of the patients in the intervention group and $78 \%$ in the control group who had beta blocker therapy at the end of the study $(\mathrm{p}=0.52)$. The average dosage level of beta blockades at baseline was $33 \%$ in both groups. At the end of the study, the average dosage level was increased to $46 \%$ in the intervention group and in the control group the dosage level was $36 \%(\mathrm{p}=0.10)$.

\section{Compilation of composite endpoints}

A summary of the composite endpoint consisting of survival, echocardiography, NT-proBNP, hospitalization and physical component scale and mental component scale was calculated to further highlight the effects of the intervention and is illustrated in Table VI. In this compilation, the most obvious impacts are in NT-proBNP $(\mathrm{p}=0.003)$ and in the QoL variable mental component scale $(\mathrm{p}=0.04)$. The summarized composite endpoints resulted in a significantly higher score in the intervention group.

Table VI. Composite endpoint calculation including survival, echocardiography, NT-proBNP concentration, hospital admission and two components of health-related quality of life within the intervention and the control group of the study population.

\begin{tabular}{lccc} 
& $\begin{array}{c}\text { Intervention group } \\
\text { (points) }\end{array}$ & $\begin{array}{c}\text { Control group } \\
\text { (points) }\end{array}$ & P-value \\
\hline Survival & -12 & -15 & 0.76 \\
Echocardiography & 11 & 10 & 0.85 \\
NT-proBNP & 50 & 0 & 0.003 \\
Hospital admission & -24 & -32 & 0.23 \\
Physical Component Scale & 6 & 17 & 0.50 \\
Mental Component Scale & 10 & -29 & 0.04 \\
Summarized points & 25 & -37 & 0.01 \\
\hline
\end{tabular}

Note: The term 'hospital admission' refers to admissions caused by cardiovascular disease.

\section{NYHA functional classes}

There were no significant differences regarding NYHA functional classes between the groups at baseline or at the end of the study. The distribution of the NYHA classes is illustrated in Table VII. In the intervention group at baseline, there were slightly fewer patients in NYHA class I, more patients in NYHA-class II, and fewer patients in NYHA class III compared to the control group. There were no significant differences in NYHA classes between the groups at the end of the study. The number of patients in NYHA class I in the intervention group had increased from three to eight patients at the end of the study but was unchanged in the control group. 
Table VII. Distribution of NYHA functional classes of the patients included in the study before and after the study period.

\begin{tabular}{lrrrrr}
\hline & $\begin{array}{c}\text { Before } \\
\text { Intervention } \\
\text { Group }\end{array}$ & $\begin{array}{c}\text { Control } \\
\text { Group }\end{array}$ & p-value & $\begin{array}{c}\text { Intervention } \\
\text { Group }\end{array}$ & $\begin{array}{c}\text { After } \\
\text { Control } \\
\text { Group }\end{array}$ \\
p-value
\end{tabular}

\section{Cardiac function with echocardiography}

A calculation was performed for patients with $\mathrm{EF}<40 \%$ according to echocardiography. It was not possible at baseline to detect a difference in the number of patients with $\mathrm{EF}<40 \%$ between the groups ( $39 / 71$ vs. $\left.44 / 70 ; \chi^{2}: 0.91 ; p=0.34\right)$. At the end of the study, the intervention group had significantly fewer patients with $\mathrm{EF}<40 \%$ compared to the control group $\left(33 / 71\right.$ vs. $\left.45 / 70 ; \chi^{2}: 4.88 ; p=0.03\right)$. All the results of echocardiography are specified in Table VIII.

Table VIII. All results of the echocardiographic examinations allocated in functional levels.

\begin{tabular}{|c|c|c|c|c|c|c|}
\hline & \multicolumn{3}{|c|}{ BEFORE } & \multicolumn{3}{|c|}{ AFTER } \\
\hline & $\begin{array}{l}\text { Intervention } \\
\text { Group }\end{array}$ & $\begin{array}{l}\text { Control } \\
\text { Group }\end{array}$ & p-value & $\begin{array}{l}\text { Intervention } \\
\text { Group }\end{array}$ & $\begin{array}{l}\text { Control } \\
\text { Group }\end{array}$ & p-value \\
\hline Echocardiography & & & 0.20 & & & 0.13 \\
\hline $\mathrm{EF} \geq 50 \%, \mathrm{n}(\%)$ & $0(0)$ & $0(0)$ & & $7(9)$ & $8(11)$ & \\
\hline $\mathrm{EF} 40-49 \%, \mathrm{n}(\%)$ & $32(41)$ & $27(33)$ & & $32(43)$ & $17(23)$ & \\
\hline EF $30-39 \%, \mathrm{n}(\%)$ & $37(47)$ & $35(43)$ & & $25(34)$ & $32(44)$ & \\
\hline $\mathrm{EF}<30 \%, \mathrm{n}(\%)$ & $10(13)$ & $19(23)$ & & $8(11)$ & $13(18)$ & \\
\hline Missing & & & & $2(3)$ & $3(4)$ & \\
\hline
\end{tabular}

Note; EF: ejection fraction; n; number; Missing, Not attend final echocardiography

\section{Cardiac function assessed with natriuretic peptides}

At the start of the study, there was no difference in NT-proBNP levels between the groups. The mean value in the intervention group was $1091 \mathrm{ng} / \mathrm{L}$ (median $1734 \mathrm{ng} / \mathrm{L}$ ), while in the control group it was $588 \mathrm{ng} / \mathrm{L}$ (median $1137 \mathrm{ng} / \mathrm{L})(\mathrm{p}=0.07)$. The mean value of NT-proBNP at the end of the study was $895 \mathrm{ng} / \mathrm{L}$ (median $1354 \mathrm{ng} / \mathrm{L}$ ) in the intervention group, and 671 $\mathrm{ng} / \mathrm{L}(1234 \mathrm{ng} / \mathrm{L})(\mathrm{p}=0.7)$ in the control group.

\section{The assessment of health-related quality of life}

The outcomes of the QoL measurements obtained in eight different dimensions according to SF-36 are demonstrated in Figure 4. None of the dimensions demonstrated a significant difference in QoL between the intervention group and the control group. However, the dimension "Role Emotional" displayed a p-value of 0.06 which was the most apparent difference of all analysed dimensions between the intervention and the control groups. 
Figure 4. Differences in $\mathrm{SF} 36$ variables between the start and end of the study. $\mathrm{PF}=$ physical function, $\mathrm{RP}=\mathrm{role}$ physical, $\mathrm{BP}=$ body pain, $\mathrm{GH}=$ general health, $\mathrm{VT}=$ vitality, $\mathrm{SF}=$ social function, $\mathrm{RE}=$ role emotional, $\mathrm{MH}=$ mental health.

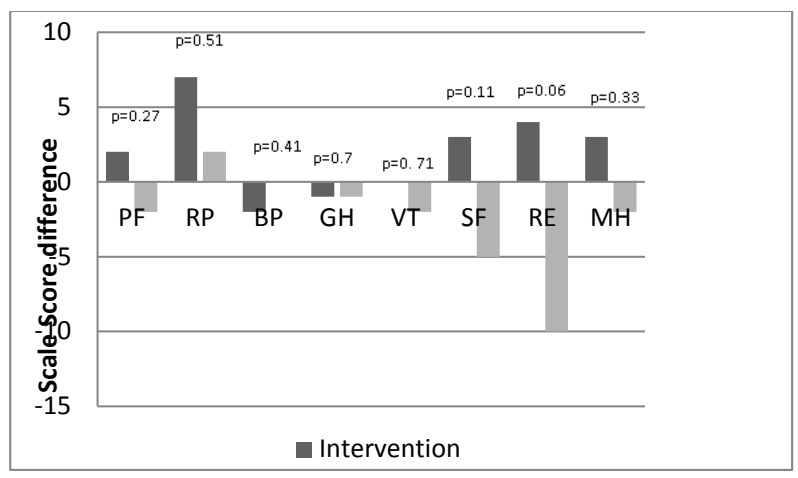

\section{The utilization of healthcare resources}

The utilization of healthcare contacts in the HC, PHC and in total is shown in Table IX. There was no significant difference in the number of contacts between the intervention group and the control group in $\mathrm{HC}$ or PHC contacts ( $\mathrm{p}=0.13$ and 0.51 ). However, there was a significant difference overall in the number of contacts, with the intervention group having a lower number of contacts $(\mathrm{p}=0.04)$.

An assessment of the number of visits to the emergency ward showed that the patients in the intervention group had 38 visits and patients in the control group had 62 visits $(\mathrm{p}=0.002)$. The patients in the intervention group had 36 admissions to hospital and in the control group there were 51 admissions $(\mathrm{p}=0.03$ ). Subsequently, the intervention group had fewer patients who visited the emergency ward without subsequent hospitalization (two visits versus 11 visits $(\mathrm{p}=0.0001))$. There were 24 patients in the intervention group who were admitted at least once, and in the control group there were 32 patients with at least one admission to hospital $(\mathrm{p}=0.06)$. Among patients who were admitted to hospital on any occasion, the number of hospital days on average was 8.3 days and there was no difference between groups.

Regarding the number of hospital days, the intervention group had an average of 3.4 days per patient and the control group had 5.2 hospital days on average, which was not a significant difference $(\mathrm{p}=0.16)$, and which is shown in detail in Table $X$. The intervention group had significantly fewer (0.4) visits to HC physicians, and in the control group there were 0.8 visits $(\mathrm{p}=0.01)$. In the intervention group, the number of outpatient visits to nurses was on average 0.1 visits, and in the control group $0.6(\mathrm{p}=0.004)$.

The healthcare utilization in the PHC is also illustrated in table X. The number of visits to the GP was 2.9 visits in the intervention group and 3.8 visits in the control group $(\mathrm{p}=0.02)$.

Regarding visits to the district nurse, there were 4.4 visits in the intervention group and 7.8 in the control group $(\mathrm{p}=0.14)$. The number of visits to specialized nurses in the PHC was 1.7 visits on average in the intervention group, and in the control group it was $1.6(\mathrm{p}=0.08)$. Furthermore, there were significantly more visits by the intervention group during the first six weeks $(1.1$ versus 0.2 visits $(\mathrm{p}=0.02))$. 
Table IX. Utilization of healthcare in the intervention group and control group. The utilization of hospital care, primary healthcare and total contact is illustrated both in total numbers and as mean values.

Intervention Group Control Group Visits or Days Visits or Days p-value

\section{Hospital Care}

Inpatient care

Number of admissions

$36 \quad 51$

Number of days in a hospital ward; $\mathrm{n}$

265

423

Outpatient care

Emergency ward, $\mathrm{n}$

Visit to physician, $n$

Visit to a heart failure nurse, $\mathrm{n}$

Total number of days for hospital care; $n$

Number of contacts/patients; mean (SD)

\section{Primary Healthcare}

Visits related to general practitioner

Visits, $\mathrm{n}$

Administrative (prescription/telephone), $\mathrm{n}$

Visits related to nurses

Visit to specialized nurse, $\mathrm{n}$

Visits, $\mathrm{n}$

Visits related to para medical staff

Paramedicine, $\mathrm{n}$

Total number of contacts with PHC; $\mathrm{n}$

Total number of contacts with PHC \& HC; $n$

$1291 \quad 1964$

Total number of contacts/patient for PHC \& HC; mean (SD)

$16.3(18.0) \quad 24.2(28.7)$

Note: n=number; SD, standard deviation; HC, Hospital Care; Paramedical staff, physiotherapist, occupationa therapist, dietician, podiatrist; PHC, primary healthcare.

Calculations were made of the average cost for the variables HC, PHC, examinations, medication, and the total cost, all of which are illustrated in Table X. The cost of the HC was EUR 2698 in the intervention group and EUR 4331 in the control group $(\mathrm{p}=0.02)$. The cost for PHC was EUR 1254 in the intervention group and EUR 1777 in the control group $(p=0.02)$. In total, the cost for the intervention group was EUR 4407 while in the control group it was EUR $6590(\mathrm{p}=0.01)$. This implies that the intervention resulted in a cost reduction of EUR 2183 per patient $(33 \%)$.

When estimating the cost for the intervention, it was assessed that the cost was EUR 332, which includes the cost of 222 EUR for nurse visits and EUR 110 for visits to the GP. 
Table X. Mean healthcare costs, study visits and inpatient days per patient distributed in hospital, examinations, primary care and medication for patients allocated to the intervention group as well as the control group.

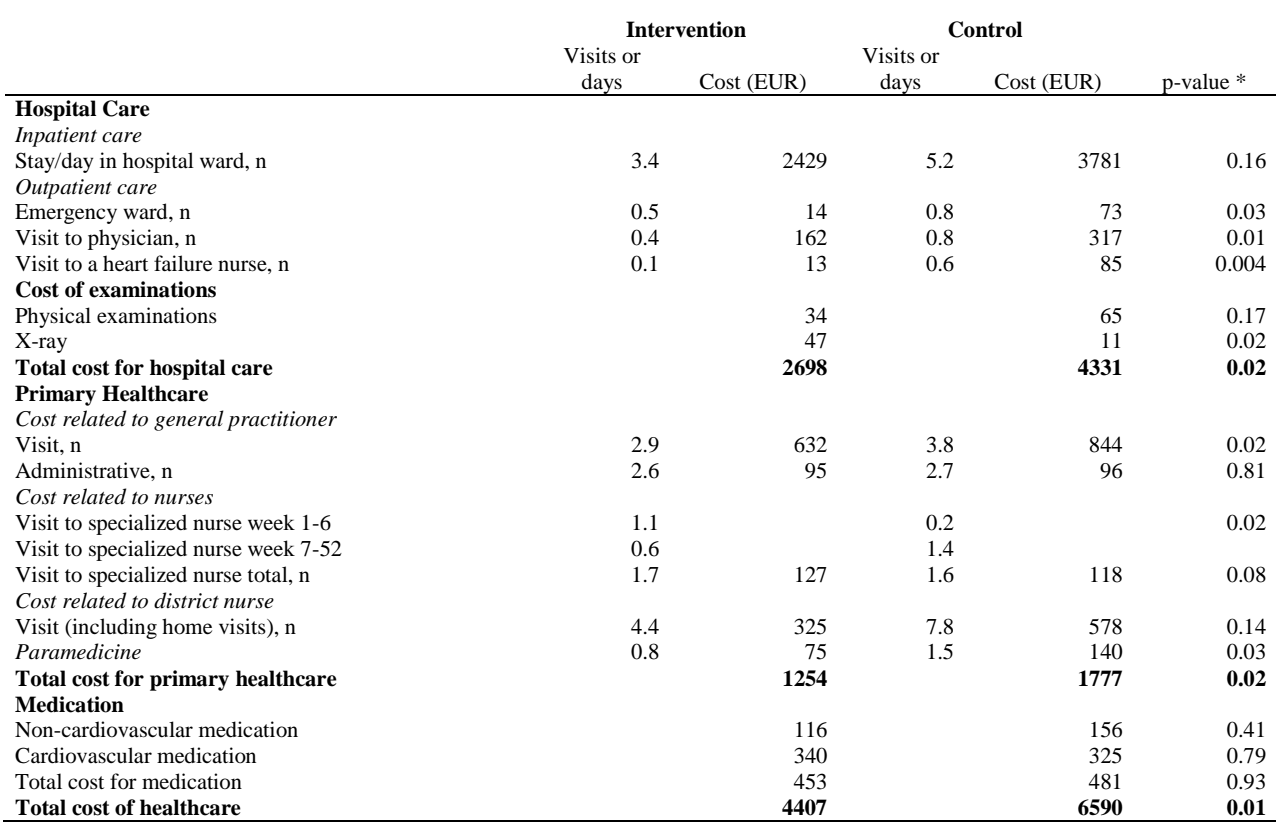

Note: n; numbers, Administrative; prescription/telephone,

Non-parametric tests have been used in table $\mathrm{X}$ when comparing costs. * P-value under null hypothesis of no cost difference between the groups.

\section{DISCUSSION}

Studies on HFMPs have shown that they reduce mortality and hospitalization $(99,101)$. These studies have been mainly Hospital-based with populations probably having more severe HF, and the enrolment to these studies was usually carried out when the patients were hospitalized and their HF condition had deteriorated. In the present study (III,IV), the enrolled patients were stable in their HF condition and the HF was considered as a mild form. Therefore, the results are not completely comparable due to a difference in population, and the present study had different results in resource utilization and not mortality. Two PHC-based HFMP studies with a similar design and population to the present study have been carried out. One was from New Zealand, which showed that HFMPs in PHC after discharge reduced hospitalization by 26\%. The other was an American study, which showed a reduction by $40 \%$ in the number of visits to the hospital emergency ward. These results were similar to those found in the present study $(127,128)$. This thesis has shown that the HF population in PHC is old, and the most common etiological factors are IHD and hypertension, and only $31 \%$ are diagnosed with echocardiography (I). When an HFMP intervention was implemented in PHC, there was reduction in health care utilisation and costs (III,IV). The intervention group had a significantly lower number of health care contacts and there was also a lower (36 versus 62) number of admittances to hospital as well ( $\mathrm{p}=0.002)$. The cost of HC was EUR 2698 in the intervention group and EUR 4331 in the control group $(\mathrm{p}=0.02)$, and the costs for PHC were found to be similar since the intervention group had a cost of EUR 1254, while for the control 
group it was EUR 1777 ( $\mathrm{p}=0.02$ ). In total, the intervention group had a cost of EUR 4407 and the control group EUR $6590(\mathrm{p}=0.01)$, which is a cost reduction of $33 \%$. The intervention also resulted in a reduction of NT-proBNP and improved cardiac function but the mortality and QoL remained unchanged.

\section{Population characteristics}

The average age in the first study was 78 years and in comparison with other studies which were mainly population-based, this finding was well matched (I) $(9,15,18,91,129)$. Furthermore, the average age for women was higher in the present study, 80 for women and 76 for men $(\mathrm{p}<0.05)$, which is also congruent with comparable studies $(9,15,91)$. The reason why women were significantly older is probably that women have a later onset of HF and have their AMI 7-8 years later compared to men, probably because women have more hypertension with a later onset of HF. The prevalence of HF calculated in the population of the first study was $2 \%$ (I). There are similar findings when comparing with other studies $(5,9)$. In the study population III-IV, there was a mortality rate of $6 \%$. This is a low mortality rate since other studies have shown a mortality of $20-29 \%$ for one year and a mortality that increases markedly with age $(11,102,129)$. A Swedish register study showed mortality in an HC population of $21 \%$ and a mortality of $6 \%$ in PHC-based patients (18). Presumably, the patients in the HC population have a more severe HF compared to the patients in the PHC and therefore, it can be difficult to compare results from $\mathrm{HC}$ to PHC.

\section{Etiological factors and concomitant diseases in heart failure}

The most common etiological factors in HF are IHD and hypertension. Valvular disease and cardiomyopathy are more unusual causes of HF in an HF population, and this was also found in the present study (I, II) (1-5). Other diseases occurring in this study population were diabetes in 25\%, COPD in 14-20\% and AF in 38\%. Diabetes was present in $25 \%$ of the patients in these populations (I-III). This is consistent with other studies and, consequently, diabetes is an important component in $\mathrm{HF}(7,9,18)$. There was an occurrence of AF in 30$40 \%$ of the patients in the present populations and this finding is comparable with other studies that have $40-45 \%$ of the patients with AF (I-III) $(7,18)$.

\section{Diagnostic considerations of heart failure in primary health care}

In the first retrospective study, $69 \%$ of the patients had the diagnosis of HF based on clinical criteria and only $31 \%$ received it based on echocardiography (I). When HF is based on clinical criteria, basically $50 \%$ of the patients will have an incorrect diagnosis $(4,19,25,64)$. In comparison with other studies which are population- or PHC-based, echocardiography was applied in $8-30 \%$ of patients with the diagnosis of HF in the PHC $(6,7,97)$. Consequently, there is a substantial risk that the diagnosis is incorrect and that patient will receive inappropriate treatment. Admittedly, this data is somewhat old and therefore it can be expected that there has been an improvement in recent years. Physicians in PHC might have been cautious about using echocardiography at that time, due to low availability and possibly with regard to the cost aspect. 


\section{The use of medication in heart failure}

The retrospective study of the HF population demonstrated that treatment with RAS blockade occurred in $56 \%$ (I). However, diuretic therapy was used with $84 \%$ of the patients and was the most commonly used drug in HF (I). Digoxin was used in $40 \%$ of cases, which was roughly equivalent to the number of patients having $\mathrm{AF}$, implying that digoxin was primarily used to regulate the heart rate. Treatment with beta blockers or MRA was not considered since it was not fully recognized therapy when planning the study. In other studies, 60-70\% had treatment with RAS blockade $(7,18,64)$ Treatment with beta blockers occurred in $30-50 \%$ of the patients, which could be regarded as an underuse of medication, and when used, it was often in suboptimal dosages (I) (18). There is overwhelming evidence that these drugs have positive effects on HF when used at recommended dosages (68-75,77-81).

In the prospective study, there were no significant differences at baseline between the intervention and the control group regarding the number of patients treated with RASblockade or beta blockers. However, a significantly higher number of patients were treated with RAS-blockade in the intervention group (100 vs. $84 \%)$ at the end of the study $(\mathrm{p}=0.002)$. The dosage levels were also significantly increased in the intervention group which had $94 \%$ of the optimized dosage compared to $69 \%$ in the control group $(\mathrm{p}=0.0001)$. These results for RAS-blockade were not found in the control group, nor were they found for beta blockers in either group. The increased usage and dosages of RAS-blockade should be a result of the intervention, which might be a factor contributing to the reduction of health care utilization and health care costs.

\section{Functional capacity in heart failure}

When analysing the NYHA functional classes in all the studies, it was evident that NYHA class II (41-51\%) was the most frequent functional class, followed by NYHA class III (30-40 $\%$ ) (I-IV). NYHA class I occurred in approximately 10\% (4-17\%). Patients in NYHA class IV, however, were unusual and were only detected in $2 \%$ (I). When comparing with the COACH study, $50 \%$ of the patients were in NYHA-class II, $46 \%$ in NYHA class III and $4 \%$ in NYHA class IV. The presumption is that the COACH study had a more severe HF compared to the present studies, with a mortality which was $29 \%$ and therefore not completely comparable. In the PHC-based study illustrated, there was a distribution of NYHA classes (NYHA class I 19\%, NYHA class II 41\%, NYHA class III 24\% and NYHA class IV (7\%) and since this was a similar descriptive study as study I, these findings are considered to be comparable (7). In the present study, there were patients with NYHA class I, who would be non-symptomatic HF patients. The patients participating in the present prospective study were recruited when there had been no deterioration in HF but when they had shown impaired cardiac function in echocardiography. The explanation is that these patients previously had symptomatic HF, and after receiving HF treatment recovered to be in NYHA I.

\section{Evaluation of the composite endpoints}

Since the present study had a short intervention time and consisted of a small study population with a stable HF, it could not be expected to find significant differences in mortality and morbidity and therefore there was a calculation of composite endpoints consisting of the variables of survival, hospitalization, changes of NT-proBNP, echocardiography and QoL. However, the composite endpoints showed that the intervention group had significantly improved scores compared to the control group. 


\section{Natriuretic peptides}

The NT-proBNP was significantly decreased in the intervention group during the study period, which was not observed in the control group (III). It can be presumed that the intervention caused an increased adherence to medications and furthermore resulted in enhanced dose optimization of HF-related medications. In the UPSTEP-study, which was a BNP-guided treatment study, there was a subgroup analysis comparing responders (a reduction of $\mathrm{BNP}>30 \%$ ) with non-responders (52). This analysis illustrated significant differences in several outcomes and even in mortality. These findings should imply that the reduction of NP has an important role and has an impact on the heart failure prognosis. Furthermore, NP levels are prognostic factors $(43,56,57)$. The SIGNAL-study, with NTproBNP-guided management of HF patients in the PHC, did not result in improved treatment and was not able to show changes in mortality or morbidity (130). The study did not, however, have similar intervention as in present study (III). This study was not designed to evaluate NT-proBNP-guided management, but it appears that optimized medication and (probably) increased adherence to medication are important factors.

\section{Cardiac function}

The cardiac function was analysed with echocardiography and, at baseline, and there was no significant difference between the two groups (III) in the number of patients with EF $<40 \%$. After the intervention, there were significantly fewer patients with EF $<40 \%$ in the intervention group. Even though this is a small study population with patients with milder forms of $\mathrm{HF}$, it was possible to demonstrate an improvement in cardiac function. This indicates that it was possible to show improvement even in cardiac function assessed by echocardiography. When cardiac function was evaluated using echocardiographic examination, differences could be found in the number of patients with $\mathrm{EF},<40 \%$ after the intervention, with fewer patients in the intervention compared with the control group, even though no significant difference between the two groups could be found at the start of the intervention.

\section{Assessment of Quality of life}

There are several instruments used for measuring QoL. There are QoL instruments that are disease-specific, where Minnesota living with HF (MLHF) and Kansas City Cardiomyopathy Questionnaire (KCCQ) are frequently used instruments in HF. In the disease-specific QoL instruments, there is an emphasis on problems which are specific to HF. There are also generic QoL instruments which are broader and more extensive, which makes them more useable for patients with different characteristics and diseases. Such instruments are SF-36 and EQ-5D, but in this context, SF-36 was selected since it is a commonly used QoL instrument all over the world. Since there would be extensive comorbidity and an elderly population in the present study, the QoL instrument SF-36 would be more applicable in this study. SF-36 is a questionnaire which has been validated for $\operatorname{HF}(113,131)$. A comparative German study conducted in a PHC population using SF-36 revealed small differences in favour of the intervention in QoL regarding mental component scale and physical functioning scale, even though these were not significant (104). There was a significant change in the intervention for vitality scale but not in any of the other scales in SF-36. It is probably difficult to obtain enhancements in QoL in studies which are conducted in a PHC setting, especially when the patients have been enrolled when they had preserved health. QoL assessed with SF-36 revealed no statistical differences in any of the eight dimensions in the present study. There was a positive tendency in the intervention group, although it was not significant. In the control group, negative readings in six of eight dimensions were confirmed. 
Meanwhile, in the intervention group, there were negative readings in two dimensions and positive readings in the remaining six.

\section{The resource utilization}

In the present study, there was decreased resource utilization in the intervention group regarding days in hospital, outpatient visits to HC and PHC (II-IV). Regarding the number of days in hospital, there were, on average, 4.4 days in hospital in study II. In the following prospective study, there were, on average, 5.2 days in hospital in the control group but in the intervention group, this was reduced to 3.4 days in hospital (III-IV). Although this difference is not significant, it indicates that the intervention had an impact on the hospitalization. In comparison, two Swedish studies had an average of 6.7 hospital days per year, which is higher than the control group in the present study $(110,111)$. There are differences in these studies since one study had a higher number of hospitalizations and the other study recruited patients when hospitalized, which indicates that these patients possibly had more need of $\mathrm{HC}$ compared to those in the present study. In the present study, the intervention group had 36 hospital admissions compared with $62(\mathrm{p}=0.03)$ in the control group and there were a lower number of outpatients visits to physicians and nurses at the hospital. These results are reasonable since the intervention should have an influence on these variables. The healthcare utilization in PHC was also reduced in the intervention group regarding contacts with GP and district nurses, which would also be a consequence of the intervention (III,IV). The number of visits to a GP in the intervention group was 2.9 visits per year and in the control group it was 3.8 visits $(\mathrm{p}=0.02)$. When comparing to the retrospective study II, there were 4.6 visits to GP which was slightly higher compared to the result for the control group. Nevertheless, in comparison with a German PHC based study there were six visits to a GP (95). In a Swedish population-based cohort study, it was demonstrated that the HF patients had approximately two visits to physicians in HC and 1.2 visits to a GP. This study included patients when performing an echocardiography of some reason why these patients were probably in more need of HC in comparison to the present study (110).

The number of visits to specialized nurses in PHC for the whole study period was the same in both groups. The visits to the specialized nurses were distributed among the visits which took place during the first six weeks and the visits conducted from week 7 and until the study was terminated. It was demonstrated that the intervention group had significantly more visits in the first six-week period and that the number of visits decreased later on. This result was expected since there was an intervention in the initial six weeks which was regarded as an investment and which later on resulted in a reduced number of visits.

The intervention resulted in a statistically significantly reduced cost in total (IV). The most prominent cost reduction, which was $38 \%$, occurred in the $\mathrm{HC}$ while the cost reduction was $29 \%$ in PHC. HC was consequently the most apparent cost driving factor which after all was remarkable since the intervention was executed in a PHC-based setting without directly focusing on HC. There are data showing that HFMPs in PHC is cost-effective compared to conventional standard care of HF (132).

The average cost per patient on a one-year basis was shown in the retrospective study to be SEK 37,100, equivalent to EUR 4264 (II). The prospective follow-up study was found to have a cost of EUR 6590 in the control group (IV). This discrepancy is basically because there are differences in the price tariffs, and to elucidate if the difference was due to the prize tariffs, there was a calculation using both price tariffs in the population in study II and the control 
group of study IV, and no significant difference was found. The intervention group had a lower cost of EUR 4407 which was a reduction of $33 \%$ ( $\mathrm{p}=0.01)$. In two Swedish studies, the cost was EUR 5700-7610 and in a German study, there was a cost of EUR 4681 per year $(95,110,111)$. These comparative costs are approximately at the same level as cost of EUR 6590 representing the control group in the present study. There are probably several reasons for these differences in costs, including differences in population and there could possibly be differences in the price tariffs. These factors are probably the reason for the difference found in the allocated costs in HC and PHC. In study II, HC accounted for half the cost and PHC accounted for $22 \%$ (II). In the prospective study IV, the $\mathrm{HC}$ was still the prominent cost driving factor, representing approximately $65 \%$ of the costs while the PHC accounted for about $28 \%$ of the costs, which is a higher proportion than previously described. These findings are obviously different from comparative studies where $\mathrm{HC}$ accounted for $70 \%$ or even $84 \%$ while PHC accounted for a minor proportion, confirming the differences between the studies $(107,110,111)$. The studies illustrating that $\mathrm{HC}$ represents $70 \%$ of the costs are register studies from Stockholm. These registers were HC-based and PHC was not well represented. Furthermore, the results may have been influenced by the presence of a high number of private PHC facilities in Stockholm area with closed systems of medical health care records, and the PHC might not have been properly included in the registers. The included patients were in contact with $\mathrm{HC}$ which should result in differences in populations.

It was also found that the implementation of HFMPs in PHC resulted in a cost reduction of EUR 2183 (33\%). The stipulated cost of the intervention was EUR 332whereas the overall cost reduction was EUR 1851. This would result in a cost reduction in a population of 100 000 inhabitants of EUR 185 million.

\section{Limitations of the research}

This research might have been unsuccessful in including patients with severe HF. It is possible that HF patients with very serious conditions and needing advanced $\mathrm{HC}$ were not included in the present study since the population in this study were solely enrolled in the PHC. As the severely deteriorated patients with recurrent requirements of advanced HC, this may have affected the cost. During the study period, there were no patients included in the present study who were being considered for transplantation or devices such as ICD or CRT. These severe conditions would be more common in $\mathrm{HC}$ but would be very rare in a PHC population and should not have a substantial impact on the costs.

The study had a relatively short follow-up, which will cause difficulties in obtaining statistical outcomes on certain variables. At the same time, there was a relatively small study population which also might have made it difficult to find significance in some variables.

The study was carried out at several PHC centres and there could be a risk that the regular physicians, the GPs at the PHC centres, were influenced by the study. This may have prompted these physicians to provide enhanced management and treatment of patients in the control group. 


\section{Conclusions}

- The average age was about 78 years (I). The diagnosis of HF in the PHC was preferably based on clinical criteria, and only $31 \%$ were subjected to echocardiography in order to determine cardiac dysfunction. Women had a slightly higher average age than men. In addition, women had to a lesser extent been subjected to examination with echocardiography, and were treated more often with diuretics and more rarely with RAS blockade.

- The cost for a patient with heart failure was SEK 37 100, which gives a total cost for HF in Sweden in the range of SEK 5.0-6.7 billion, much higher than previously known (II). There were no significant differences in cost concerning gender, NYHA class, age, or heart function assessed by echocardiography. PHC accounted for a greater part of the total costs than previously assumed.

- Implementation of an HFMP in the PHC resulted in improved cardiac function, reduction in NT-proBNP and reduction of health care utilization. I did show statistically unchanged QoL and had no effect on mortality (III).

- The intervention with an HFMP in PHC entailed a reduction of resource utilization and a reduction of health care costs by $33 \%$ (IV).

\section{The research implications}

\section{The implementation of the research}

These results imply that HFMPs can be recommended in PHC. However, there can be obstacles since the PHC centres are different in size, population, localisation and traditions. A small PHC centre with young population and located close to a hospital will probably have trouble finding enough patients to uphold sufficient HF experience. However, larger PHC centres, located far from the hospital and with an older population will probably experience a positive outcome with HFMP. A PHC centre with a functional HFMP would have improved management of patients being discharged from hospital after deterioration of HF. The contact with HF nurses in PHC would involve providing information about $\mathrm{HF}$ and treatment of HF which would increase adherence to treatment and self-management to avoid worsening of HF. It also involves optimizing treatment which entails an increased welfare and improved cardiac function. HFMP probably contributes to increasing the patient's self-confidence and continuity of health care.

\section{Future research}

Forthcoming research should further investigate where the HF patients receive their health care from a much wider perspective. Recent implementation of data registers and integrated medical health care records make it possible to conduct research using more expanded and precise information regarding $\mathrm{HC}, \mathrm{PHC}$ and investigations.

It would also be of interest to investigate the HFMP implementation in a larger population in order to confirm the positive outcomes. 
This thesis did not elucidate what factor or factors influence the reduction of resource utilization and costs. Therefore, it would be interesting to elucidate such factors and how they affect the outcome. Further research should investigate if it is the improved medication, the efforts from the HF nurses or increased accessibility of health care that affect the outcome. 


\section{SUMMARY IN SWEDISH}

Hjärtsvikt kan betraktas som ett kliniskt syndrom som inte är en primär sjukdom utan sekundär till annat tillstånd som ger upphov till nedsatt hjärtfunktion. De vanligaste orsakerna till hjärtsvikt är ischemisk hjärtsjukdom och hypertoni. Hjärtsvikt är ett allvarligt tillstånd med dålig prognos som ofta drabbar den äldre populationen. Hjärtsvikt kräver omfattande sjukvårdsresurser och betraktas som ett av de mest kostsamma tillstånden inom sjukvården. Det finns numera avancerad läkemedelsbehandling som innebär att patienter med hjärtsvikt kan få en förbättrad hjärtfunktion som innebär ökad livskvalitet, minskat behov av sjukhusvård och minskad dödlighet. Undersökningar har visat att patienter med hjärtsvikt ofta inte får sådan läkemedelsbehandling. Specialiserade hjärtsviktsmottagningar har införts och visat positiva effekter när det gäller dödlighet och även sjuklighet men är mestadels visade på sjukhuspopulationer. Det är inte visat om specialiserade hjärtsviktsmottagningar kan positiva effekter även i primärvård. Sjukhusets mottagningar har patienter med hjärtsvikt som är svårare och oftare instabila. I primärvården förekommer patienter som har en mer måttlig till mild grad av hjärtsvikt som är stabil utan större behov av återkommande sjukhusinläggningar och följaktligen skiljer sig patienter med hjärtsvikt i primärvården.

Detta forskningsarbete omfattade fyra delarbeten och det inledande arbetet var en deskriptiv retrospektiv studie med 256 patienter som behandlades för hjärtsvikt i Åtvidabergs kommun (I). Syftet var att beskriva hjärtsvikt i primärvården beträffande förekomst, orsak till hjärtsvikt, handläggning av utredning, behandling samt värdera om det förelåg några könsskillnader. Resultatet var att ischemisk hjärtsjukdom följd av hypertoni är det den dominerande orsaken till hjärtsvikt. Behandlingen bestod av diuretika (84\%), ACE-hämmare (56\%) och digoxin (40\%). Det var endast $31 \%$ som hade bekräftat diagnosen hjärtsvikt med ekokardiografi. Följaktligen var det $69 \%$ som fick sin hjärtsviktsdiagnos baserad på kliniska kriterier (klinisk undersökning, EKG eller lungröntgen) trots att detta innebär många diagnoser blir felaktiga. Det fanns könsskillnader beträffande behandling och diagnostisering eftersom kvinnorna mer sällan fick behandling med ACE-hämmare och mer sällan fick genomgå ekokardiografi jämfört med männen.

Syftet med det andra delarbetet var att beräkna sjukvårdsutnyttjande, sjukvårdsrelaterade kostnader samt ta reda på om det förelåg könsskillnader (II). Detta var en retrospektiv undersökning genomförd vid två vårdcentraler. Det samlades in 115 patienter med diagnosen hjärtsvikt som fick utföra ekokardiografi för att fastställa hjärtfunktionen. Därefter granskades journaler och data samlades in angående antal vårddagar på sjukhus, besök på sjukhus och vårdcentral samt läkemedelsförbrukning och genomförda undersökningar. Resultatet blev att kostnaden för en patient med hjärtsvikt var i genomsnitt under ett år SEK 37100. Det gick inte att påvisa någon kostnadsskillnad beträffande, kön, ålder, NYHA-klasser eller hjärtfunktion. Det var sjukhusvården som svarade för den största kostnaden som var $47 \%$, primärvården $22 \%$, läkemedelsbehandlingen $18 \%$, sjukhem $5 \%$ och undersökningar stod för $6 \%$ av kostnaden.

De tredje och fjärde delarbetena som sedan genomfördes var en randomiserad, prospektivt, öppen studie med syftet att undersöka om intervention med hjärtsviktsmottagning i primärvården medför förbättrad hjärtfunktion, ökad livskvalitet och om det därigenom går att påverka sjukvårdsutnyttjande och sjukvårdsrelaterade 
kostnader (III, IV). Det inkluderades 160 patienter som randomiserades till interventionsgrupp eller till kontrollgrupp. Patienterna i interventionsgruppen fick uppföljning av hjärtsviktsutbildad sjuksköterska samt läkare innehållande information och utbildning om hjärtsvikt. Dessutom intensifierades läkemedelsbehandlingen till rekommenderade nivåer för hjärtsvikt. Resultatet blev signifikant förbättring av samansatta "endpoints" (bestående av död, hospitalisering, förändringar i NT-proBNP, ekokardiografi) i interventionsgruppen. Det blev även signifikant förbättrad hjärtfunktion med lägre NT-proBNP och förbättrad ekokardiografi. Interventionen innebar även minskade sjukvårdskontakter, färre akuta besök på akutmottagningar och färre inläggningstillfällen. Däremot blev det inte någon förbättring i livskvalitet eller funktionsförmåga vilka var oförändrade. Kostnaden minskade från EUR 6590 till EUR 4290 vilket innebär en signifikant kostnadsreduktion på $33 \%$.

Sammanfattningsvis är hjärtsvikt vanligt förekommande i primärvården och består av patienter med hög ålder. Det finns brister avseende diagnostisering av hjärtsvikt eftersom endast $31 \%$ genomgått ekokardiografi och att det i detta avseende finns könsskillnader. Intervention med hjärtsviktsmottagning i primärvården har visat att det är möjligt att minska behovet av sjukvårdskontakter samt minska sjukvårdskostnaderna. 


\section{ACKNOWLEDEMENTS}

There have been several persons during the course of this thesis which have generously contributed and for that I am deeply, forever grateful. There are several patients taking part in the study that have generously sacrificed time and in many ways contributed enormously which made the research possible.

Urban Alehagen, my tutor, for competently guiding me through my research and for helping me to find resourceful and clever solutions to all difficulties. For the admirable devotion to research and heart failure which have been inspiring for me.

Ulf Dahlström, my tutor, for having listened to my research thoughts in the beginning, giving me the opportunity to pursue my research and giving me the guidance during my research.

Mats Foldevi, my co-tutor and co-author, for bringing on my interest for research and supported me through my research and also for being there for me when it was needed.

The research nurses Ulla Nilsson, Katarina Koerfer, Ann Arvidsson, Margaretha Janefjord and Kerstin Eriksson who have with an impressive loyalty and competence helped me immensely in making the research achievable.

My colleague Stig Eriksson for the efforts and work with the research conducted in Vimmerby.

The colleagues Laila Hübbert and Lena Lindström, for the genuinely appreciated and incredible assistance in completing numerous echocardiographic investigations which was necessary to follow through with the research.

Lars-Erik Larsson, colleague in the Department of Medicine in Västervik, for completing numerous echocardiographic investigations.

The colleagues and other staff at the participating health care centres in Atvidaberg, Kungsgatan, Ekholmen and Johannelund and Vimmerby for all the help and especially the positive attitude to solving practical issues and difficulties that arose.

Kerstin Gustavsson, research nurse at the Department of Cardiology, for always being helpful and supportive during my research.

Peter Johansson, nurse at the Department of Cardiology, for the enthusiastic help with statistical dilemmas and for the excellent solutions.

Björn Tilling, my colleague and my tutor through my medical training to be a GP, for giving me the opportunity to begin my research.

Michael Nilsson, my current health care manager, for encourage me and giving me the opportunity to finish my research.

Lars Borgqvist, my co-author, for the support and guidance throughout my second article.

Thomas Paulsson, my co-author, for helping me enormously with economic issues and problems. 
Karin, my lovely wife, for always being adoring, devoted, supportive and for the incredible patience throughout the years.

Pontus, Mattias and Josefin, my wonderful children, for being understanding when their father has not been as sufficient as he wanted to be.

Marianne, my mother, for being such a supportive friend that never had stopped believing in me.

Lotta och Johan, my sister and brother, for being such close affectionate friends.

My in-laws Margareta and Hasse for their support and faith that I will succeed.

\section{GRANTS}

This research was supported by a grant from the Medical Research Council of Southeastern Sweden (FORSS) and the County Council of Östergötland. 


\section{REFERENCES}

1. Levy D, Larson MG, Vasan RS, Kannel WB, Ho KK. The progression from hypertension to congestive heart failure. JAMA 1996;275:1557-62.

2. Kannel WB. Incidence and epidemiology of heart failure. Heart Fail Rev 2000;5:16773.

3. Fox KF, Cowie MR, Wood DA, Coats AJ, Gibbs JS, Underwood SR, Turner RM, Poole-Wilson PA, Davies SW, Sutton GC. Coronary artery disease as the cause of incident heart failure in the population. Eur Heart J 2001;22:228-36.

4. Alehagen U, Lindstedt G, Levin LA, Dahlström U. The risk of cardiovascular death in elderly patients with possible heart failure. Results from a 6-year follow-up of a Swedish primary care population. Int J Cardiol 2005;100:17-27.

5. Mosterd A, Hoes AW. Clinical epidemiology of heart failure. Heart 2007;93:1137-46.

6. Halling A, Berglund J. Diagnosis and treatment of heart failure in primary health care among elderly patients with non-insulin-dependent diabetes mellitus, with special reference to use of echocardiography. Scand J Prim Health Care 2003;21:96-98.

7. Dahlström U, Håkansson J, Swedberg K, Waldenström A. Adequacy of diagnosis and treatment of chronic heart failure in primary health care in Sweden. Eur J Heart Fail, 2009;11:92-8.

8. Redfield MM, Jacobsen SJ, Burnett JC Jr, Mahoney DW, Bailey KR, Rodeheffer RJ. Burden of systolic and diastolic ventricular dysfunction in the community: appreciating the scope of the heart failure epidemic. JAMA. 2003;289:194-202.

9. Zarrinkoub R, Wettermark B, Wändell P, Mejhert M, Szulkin R, Ljunggren G, Kahan T. The epidemiology of heart failure, based on data for 2.1 million inhabitants in Sweden. Eur J Heart Fail 2013;15:995-1002.

10. McDonagh TA1, Morrison CE, Lawrence A, Ford I, Tunstall-Pedoe H, McMurray JJ, Dargie HJ. Symptomatic and asymptomatic left-ventricular systolic dysfunction in an urban population. Lancet 1997;350:829-33.

11. Curtis LH, Whellan DJ, Hammill BG, Hernandez AF, Anstrom KJ, Shea AM, Schulman KA. Incidence and prevalence of heart failure in elderly persons, 19942003.Arch Intern Med. 2008;168:418-24.

12. Mårtensson J, Strömberg A, Dahlström U, Karlsson JE, Fridlund B. Patients with heart failure in primary health care: effects of a nurse-led intervention on health-related quality of life and depression. Eur J Heart Fail 2005;7:393-403.

13. MacIntyre K, Capewell S, Stewart S, Chalmers JW, Boyd J, Finlayson A, Redpath A, Pell JP, McMurray JJ. Evidence of improving prognosis in heart failure: trends in case fatality in 66547 patients hospitalized between 1986 and 1995. Circulation 2000;102:1126-31. 
14. Varela-Roman A, Gonzalez-Juanatey JR, Basante P, Trillo R, Garcia-Seara J, MartinezSande JL, Gude F. Clinical characteristics and prognosis of hospitalised inpatients with heart failure and preserved or reduced left ventricular ejection fraction. Heart. 2002;88:249-54.

15. Bleumink GS, Knetsch AM, Sturkenboom MC, Straus SM, Hofman A, Deckers JW, Witteman JC, Stricker BH. Quantifying the heart failure epidemic: prevalence, incidence rate, lifetime risk and prognosis of heart failure The Rotterdam Study. Eur Heart J. 2004;18:1614-9.

16. Stewart S, MacIntyre K, Hole DJ, Capewell S, McMurray JJV. More 'malignant' than cancer? Five-year survival following a first admission for heart failure. Eur J Heart Fail 2001;3:315-22.

17. Shafazand M, Schaufelberger M, Lappas G, Swedberg K, Rosengren A. Survival trends in men and women with heart failure of ischaemic and non-ischaemic origin: data for the period 1987-2003 from the Swedish Hospital Discharge Registry. Eur Heart J 2009; 30:671-678.

18. Jonsson $\AA$, Edner M, Alehagen U, Dahlström U. Heart failure registry: a valuable tool for improving the management of patients with heart failure. Eur J Heart Fail 2010;12:25-31.

19. Oudejans I, Mosterd A, Bloemen JA, Valk MJ, van Velzen E, Wielders JP, Zuithoff NP, Rutten FH, Hoes AW. Clinical evaluation of geriatric outpatients with suspected heart failure: value of symptoms, signs, and additional tests. Eur J Heart Fail 2011;13:518-27.

20. Devroey D, Van Casteren V. Signs for early diagnosis of heart failure in primary health care. Vasc Health Risk Manag 2011;7:591-6.

21. Thomas JT, Kelly RF, Thomas SJ, Stamos TD, Albasha K, Parrillo JE, Calvin JE. Utility of history, physical examination, electrocardiogram, and chest radiograph for differentiating normal from decreased systolic function in patients with heart failure. Am J Med 2002;112:437-445.

22. Fonseca C, Oliveira AG, Mota T, Matias F, Morais H, Costa C, Ceia F; EPICA Investigators. Evaluation of the performance and concordance of clinical questionnaires for the diagnosis of heart failure in primary care. Eur J Heart Fail 2004;6:813-22.

23. Fonseca C. Diagnosis of heart failure in primary care. Heart Fail Rev 2006;11:95-107.

24. Kelder JC, Cramer MJ, van Wijngaarden J, van Tooren R, Mosterd A, Moons KG, Lammers JW, Cowie MR, Grobbee DE, Hoes AW. The diagnostic value of physical examination and additional testing in primary care patients with suspected heart failure. Circulation 2011;124:2865-73.

25. Rutten F H, Grobbee DE, Hoes AW. Differences between general practitioners and cardiologists in diagnosis and management of heart failure: a survey in every-day practice. Eur J Heart Fail 2003;5:337-44.

26. Hawkins NM, Petrie MC, Jhund PS, Chalmers GW, Dunn FG, McMurray JJ. Heart failure and chronic obstructive pulmonary disease: diagnostic pitfalls and epidemiology. Eur J Heart Fail 2009;11:130-9.

27. Daniels LB, Clopton P, Bhalla V, Krishnaswamy P, Nowak RM, McCord J, Hollander JE, Duc P, Omland T, Storrow AB, Abraham WT, Wu AH, Steg PG, Westheim A, Knudsen CW, Perez A, Kazanegra R, Herrmann HC, McCullough PA, Maisel AS. How 
obesity affects the cut-points for B-type natriuretic peptide in the diagnosis of acute heart failure. Results from the Breathing Not Properly Multinational Study. Am Heart J 2006;151:999-1005.

28. Struthers AD. Ten years of natriuretic peptide research: a new dawn for their diagnostic and therapeutic use? BMJ 1994; 308: 1615-19.

29. Stoupakis G, Klapholz M. Natriuretic peptides: biochemistry, physiology, and therapeutic role in heart failure. Heart Dis 2003;5:215-23.

30. Cowie MR, Struthers AD, Wood DA, Coats AJ, Thompson SG, Poole-Wilson PA, Sutton GC. Value of natriuretic peptides in assessment of patients with possible new heart failure in primary care. Lancet 1997;350:1349-53.

31. Ewald B, Ewald D, Thakkinstian A, Attia J. Meta-analysis of B type natriuretic peptide and N-terminal pro B natriuretic peptide in the diagnosis of clinical heart failure and population screening for left ventricular systolic dysfunction. Intern Med J 2008;38:101-13.

32. Costello-Boerrigter LC, Boerrigter G, Redfield MM, et al. Aminoterminal pro-B-type natriuretic peptide and B-type natriuretic peptide in the general community: determinants and detection of left ventricular dysfunction. J Am Coll Cardiol 2006;47:345-53.

33. de Lemos JA, McGuire DK, Khera A, et al. Screening the population for left ventricular hypertrophy and left ventricular systolic dysfunction using natriuretic peptides: results from the Dallas Heart Study. Am Heart J 2009;157:746-53.

34. Wang TJ, Larson MG, Levy D, Benjamin EJ, Kupka MJ, Manning WJ, Clouse ME, D'Agostino RB, Wilson PW, O'Donnell CJ. Impact of age and sex on plasma natriuretic peptide levels in healthy adults. Am J Cardiol 2002;90:254-8.

35. Shelton RJ, Clark AL, Goode K, Rigby AS, Cleland JG. The diagnostic utility of Nterminal pro-B-type natriuretic peptide for the detection of major structural heart disease in patients with atrial fibrillation. Eur Heart J 2006;27:2353-61.

36. Maisel A, Mueller C, Adams K Jr, Anker SD, Aspromonte N, Cleland JG, Cohen-Solal A, Dahlstrom U, DeMaria A, Di Somma S, Filippatos GS, Fonarow GC, Jourdain P, Komajda M, Liu PP, McDonagh T, McDonald K, Mebazaa A, Nieminen MS, Peacock WF, Tubaro M, Valle R, Vanderhyden M, Yancy CW, Zannad F, Braunwald E. State of the art: using natriuretic peptide levels in clinical practice. Eur J Heart Fail 2008;10:824-839.

37. Jernberg T, Stridsberg M, Lindahl B. Usefulness of plasma N-terminal proatrial natriuretic peptide (proANP) as an early predictor of outcome in unstable angina pectoris or non-ST-elevation acute myocardial infarction. Am J Cardiol 2002;89:64-6.

38. Redfield MM, Rodeheffer RJ, Jacobsen SJ, et al. Plasma brain natriuretic peptide concentration: impact of age and gender. J Am Coll Cardiol 2002;40:976-82.

39. Anwaruddin S, Lloyd-Jones DM, Baggish A, et al. Renal function, congestive heart failure, and amino-terminal pro-brain natriuretic peptide measurement: results from the ProBNP Investigation of Dyspnea in the Emergency Department (PRIDE) Study. J Am Coll Cardiol 2006;47:91-7. 
40. Mehra MR1, Uber PA, Park MH, Scott RL, Ventura HO, Harris BC, Frohlich ED. Obesity and suppressed B-type natriuretic peptide levels in heart failure. J Am Coll Cardiol 2004;43:1590-5.

41. Zaphiriou A, Robb S, Murray-Thomas T, Mendez G, Fox K, McDonagh T, Hardman SM, Dargie HJ, Cowie MR. The diagnostic accuracy of plasma BNP and NTproBNP in patients referred from primary care with suspected heart failure: results of the UK natriuretic peptide study. Eur J Heart Fail 2005;7:537-41.

42. Murdoch DR, McDonagh TA, Byrne J, Blue L, Farmer R, Morton JJ, Dargie HJ. Titration of vasodilator therapy in chronic heart failure according to plasma brain natriuretic peptide concentration: randomized comparison of the hemodynamic and neuroendocrine effects of tailored versus empirical therapy. Am Heart J 1999;138:11261132.

43. Januzzi JL Jr. Use of biomarkers to "guide" care in chronic heart failure: what have we learned (so far)? J Card Fail 2011;17:622-5.

44. Troughton RW, Frampton CM, Yandle TG, Espiner EA, Nicholls MG, Richards AM. Treatment of heart failure guided by plasma aminoterminal brain natriuretic peptide $(\mathrm{N}$ BNP) concentrations. Lancet 2000;355:1126-30.

45. Jourdain P, Jondeau G, Funck F, Gueffet P, Le Helloco A, Donal E, Aupetit JF, Aumont MC, Galinier M, Eicher JC, Cohen-Solal A, Juillière Y. Plasma brain natriuretic peptide-guided therapy to improve outcome in heart failure: the STARS-BNP Multicenter Study. J Am Coll Cardiol 2007;49:1733-9.

46. Berger R, Moertl D, Peter S, Ahmadi R, Huelsmann M, Yamuti S, Wagner B, Pacher R. $\mathrm{N}$-terminal pro-B-type natriuretic peptide-guided, intensive patient management in addition to multidisciplinary care in chronic heart failure a 3-arm, prospective, randomized pilot study. J Am Coll Cardiol 2010;55:645-53.

47. Gaggin HK, Mohammed AA, Bhardwaj A, Rehman SU, Gregory SA, Weiner RB, Baggish AL, Moore SA, Semigran MJ, Januzzi JL Jr. Heart failure outcomes and benefits of NT-proBNP-guided management in the elderly: results from the prospective, randomized ProBNP outpatient tailored chronic heart failure therapy (PROTECT) study. J Card Fail 2012;18:626-34.

48. Pfisterer M, Buser P, Rickli H, Gutmann M, Erne P, Rickenbacher P, Vuillomenet A, Jeker U, Dubach P, Beer H, Yoon SI, Suter T, Osterhues HH, Schieber MM, Hilti P, Schindler R, Brunner-La Rocca HP; TIME-CHF Investigators. BNP-guided vs symptom-guided heart failure therapy: the Trial of Intensified vs Standard Medical Therapy in Elderly Patients With Congestive Heart Failure (TIME-CHF) randomized trial. JAMA 2009;301:383-92.

49. Lainchbury JG, Troughton RW, Strangman KM, Frampton CM, Pilbrow A, Yandle TG, Hamid AK, Nicholls MG, Richards AM. N-terminal pro-B-type natriuretic peptideguided treatment for chronic heart failure: results from the BATTLESCARRED (NTproBNP-Assisted Treatment To Lessen Serial Cardiac Readmissions and Death) trial. J Am Coll Cardiol 2009;55:53-60.

50. Eurlings LW, van Pol PE, Kok WE, van Wijk S, Lodewijks-van der Bolt C, Balk AH, Lok DJ, Crijns HJ, van Kraaij DJ, de Jonge N, Meeder JG, Prins M, Pinto YM.. Management of chronic heart failure guided by individual N-terminal pro-B-type 
natriuretic peptide targets: results of the PRIMA (can PRo-brain-natriuretic peptide guided therapy of chronic heart failure IMprove heart fAilure morbidity and mortality?) study. J Am Coll Cardiol 2010;56: 2090-100.

51. Shah MR, Califf RM, Nohria A, Bhapkar M, Bowers M, Mancini DM, Fiuzat M, Stevenson LW, O'Connor CM. STARBRITE: a randomized pilot trial of BNP-guided therapy in patients with advanced heart failure. J Card Fail 2011;17:613-21.

52. Karlström P, Alehagen U, Boman K, Dahlström U; on behalf of the UPSTEP-study group. Brain natriuretic peptide-guided treatment does not improve morbidity and mortality in extensively treated patients with chronic heart failure: responders to treatment have a significantly better outcome. Eur J Heart Fail 2011;13:1096-1103.

53. Gardner RS, Ozalp F, Murday AJ, Robb SD, McDonagh TA. N-terminal pro-brain natriuretic peptide. A new gold standard in predicting mortality in patients with advanced heart failure. Eur Heart J 2003;24:1735-1743.

54. Latini R, Masson S, Anand I, et al: The comparative prognostic value of plasma neurohormones at baseline in patients with heart failure enrolled in Val-HeFT. Eur Heart J 2004;25:292-299.

55. Doust JA, Pietrzak E, Dobson A, et al: How well does B-type natriuretic peptide predict death and cardiac events in patients with heart failure: systematic review. BMJ 2005;330:625.

56. Wedel H, McMurray JJ, Lindberg M, Wikstrand J, Cleland JG, Cornel JH, Dunselman P, Hjalmarson A, Kjekshus J, Komajda M, Kuusi T, Vanhaecke J, Waagstein F; CORONA Study Group. Predictors of fatal and non-fatal outcomes in the Controlled Rosuvastatin Multinational Trial in Heart Failure (CORONA): incremental value of apolipoprotein A-1, high-sensitivity C-reactive peptide and $\mathrm{N}$-terminal pro B-type natriuretic peptide. Eur J Heart Fail 2009;11:281-91.

57. Ketchum ES, Levy WC. Establishing prognosis in heart failure: a multimarker approach. Prog Cardiovasc Dis 2011;54:86-96.

58. Davie AP, Francis CM, Caruana L, Sutherland GR, McMurray JJ. Assessing diagnosis in heart failure: which features are any use? QJM 1997;90:335-339.

59. Khunti K, Squire I, Abrams KR, Sutton AJ. Accuracy of a 12-lead electrocardiogram in screening patients with suspected heart failure for open access echocardiography: a systematic review and meta-analysis. Eur J Heart Fail 2004;6:571-576.

60. Madias JE. Why recording of an electrocardiogram should be required in every inpatient and outpatient encounter of patients with heart failure. Pacing Clin Electrophysiol 2011;34:963-7.

61. Alam M, Rosenhamer G, Höglund C. Comparability of echocardiography and chest Xray following myocardial infarction. J Intern Med 1989;226:171-5.

62. Badgett RG, Lucey CR, Mulrow CD. Can the clinical examination diagnose left-sided heart failure in adults? JAMA 1997;277:1712-9.

63. Wahls SA. Causes and evaluation of chronic dyspnea. Am Fam Physician 2012;86:173-82.

64. Hobbs FD, Korewicki J, Cleland JG, Eastaugh J, Freemantle N; IMPROVEMENT Investigators. The diagnosis of heart failure in European primary care: The 
IMPROVEMENT Programme survey of perception and practice. Eur J Heart Fail 2005; 7: 768-79.

65. Lang RM, Bierig M, Devereux RB, Flachskampf FA, Foster E, Pellikka PA,Picard MH, Roman MJ, Seward J, Shanewise J, Solomon S, Spencer KT,St John Sutton M, Stewart W. Recommendations for chamber quantification. Eur J Echocardiogr 2006;7:79-108.

66. Bursi F, Weston SA, Redfield MM, Jacobsen SJ, Pakhomov S, Nkomo VT, Meverden RA, Roger VL. Systolic and diastolic heart failure in the community. JAMA 2006;296:2209-16.

67. Kirkpatrick JN, Vannan MA, Narula J, Lang RM. Echocardiography in heart failure: applications, utility, and new horizons. J Am Coll Cardiol 2007;50:381-396.

68. Effects of enalapril on mortality in severe congestive heart failure. Results of the Cooperative North Scandinavian Enalapril Survival Study (CONSENSUS). The CONSENSUS Trial Study Group. N Engl J Med 1987;316:1429-1435.

69. Effect of enalapril on survival in patients with reduced left ventricular ejection fractions and congestive heart failure. The SOLVD Investigators. N Engl J Med 1991;325:293302.

70. The Acute Infarction Ramipril Efficacy (AIRE) Study Investigators. Effect of ramipril on mortality and morbidity of survivors of acute myocardial infarction with clinical evidence of heart failure. Lancet 1993;342:821-8.

71. Flather MD, Yusuf S, Kober L, Pfeffer M, Hall A, Murray G, Torp-Pedersen C, Ball S, Pogue J, Moye L, Braunwald E. Long-term ACE-inhibitor therapy in patients with heart failure or left-ventricular dysfunction: a systematic overview of data from individual patients. ACE-Inhibitor Myocardial Infarction Collaborative Group. Lancet 2000;355:1575-81.

72. Packer M, Poole-Wilson PA, Armstrong PW, Cleland JG, Horowitz JD, Massie BM, Ryden L, Thygesen K, Uretsky BF. Comparative effects of low and high doses of the angiotensin-converting enzyme inhibitor, lisinopril, on morbidity and mortality in chronic heart failure. ATLAS Study Group. Circulation 1999;100:2312-18.

73. Cohn JN, Tognoni G. A randomized trial of the angiotensin-receptor blocker valsartan in chronic heart failure. N Engl J Med 2001;345:1667-1675.

74. Maggioni AP, Anand I, Gottlieb SO, Latini R, Tognoni G, Cohn JN. Effects of valsartan on morbidity and mortality in patients with heart failure not receiving angiotensin-converting enzyme inhibitors. J Am Coll Cardiol 2002;40:1414-1421.

75. Granger CB, McMurray JJ, Yusuf S, Held P, Michelson EL, Olofsson B, Ostergren J, Pfeffer MA, Swedberg K. Effects of candesartan in patients with chronic heart failure and reduced left-ventricular systolic function intolerant to angiotensin-convertingenzyme inhibitors: the CHARM-Alternative trial. Lancet 2003;362:772-776.

76. McMurray JJ, Ostergren J, Swedberg K, Granger CB, Held P, Michelson EL, Olofsson B, Yusuf S, Pfeffer MA. Effects of candesartan in patients with chronic heart failure and reduced left-ventricular systolic function taking angiotensin-converting-enzyme inhibitors: the CHARM-Added trial. Lancet 2003;362:767-771.

77. The Cardiac Insufficiency Bisoprolol Study II (CIBIS-II): a randomised trial. Lancet 1999;353:9-13. 
78. Effect of metoprolol CR/XL in chronic heart failure: Metoprolol CR/XL Randomised Intervention Trial in Congestive Heart Failure (MERIT-HF). Lancet 1999; 353:2001-7.

79. Hjalmarson A, Goldstein S, Fagerberg B, Wedel H, Waagstein F, Kjekshus J, Wikstrand J, El Allaf D, Vitovec J, Aldershvile J, Halinen M, Dietz R, Neuhaus KL, Janosi A, Thorgeirsson G, Dunselman PH, Gullestad L, Kuch J, Herlitz J, Rickenbacher P, Ball S, Gottlieb S, Deedwania P. Effects of controlled-release metoprolol on total mortality, hospitalizations, and well-being in patients with heart failure: the Metoprolol CR/XL Randomized Intervention Trial in congestive heart failure (MERIT-HF). MERIT-HF Study Group. JAMA 2000;283:1295-1302.

80. Packer M, Coats AJ, Fowler MB, Katus HA, Krum H, Mohacsi P, Rouleau JL, Tendera M, Castaigne A, Roecker EB, Schultz MK, DeMets DL. Effect of carvedilol on survival in severe chronic heart failure. N Engl J Med 2001;344: 1651-58.

81. Packer M, Fowler MB, Roecker EB, Coats AJ, Katus HA, Krum H, Mohacsi P, Rouleau JL, Tendera M, Staiger C, Holcslaw TL, Amann-Zalan I, DeMets DL. Effect of carvedilol on the morbidity of patients with severe chronic heart failure: results of the carvedilol prospective randomized cumulative survival (COPERNICUS) study. Circulation 2002;106:2194-2199.

82. Krum H, Roecker EB, Mohacsi P, Rouleau JL, Tendera M, Coats AJ, Katus HA, Fowler MB, Packer M. Effects of initiating carvedilol in patients with severe chronic heart failure: results from the COPERNICUS Study. JAMA 2003;289:712-8.

83. Jondeau G, Neuder Y, Eicher JC, Jourdain P, Fauveau E, Galinier M, Jegou A, Bauer F, Trochu JN, Bouzamondo A, Tanguy ML, Lechat P. B-CONVINCED: Beta-blocker CONtinuation Vs. INterruption in patients with Congestive heart failure hospitalizED for a decompensation episode. Eur Heart J 2009;30:2186-92.

84. Pitt B, Remme W, Zannad F, Neaton J, Martinez F, Roniker B, Bittman R, Hurley S, Kleiman J, Gatlin M. Eplerenone, a selective aldosterone blocker, in patients with left ventricular dysfunction after myocardial infarction. N Engl J Med 2003;348:1309-21.

85. Zannad F, McMurray JJ, Krum H, van Veldhuisen DJ, Swedberg K, Shi H, Vincent J, Pocock SJ, Pitt B. Eplerenone in patients with systolic heart failure and mild symptoms. N Engl J Med 2011;364:11-21.

86. The Digitalis Investigation Group. The effect of digoxin on mortality and morbidity in patients with heart failure. N Engl J Med 1997;336:525-33.

87. Hood WB Jr, Dans AL, Guyatt GH, Jaeschke R, McMurray JJ. Digitalis for treatment of congestive heart failure in patients in sinus rhythm: a systematic review and metaanalysis. J Card Fail 2004;10:155-164.

88. Cody RJ, Kubo SH, Pickworth KK. Diuretic treatment for the sodium retention of congestive heart failure. Arch Intern Med 1994;154:1905-14.

89. Patterson JH, Adams KF Jr, Applefeld MM, Corder CN, Masse BR. Oral torsemide in patients with chronic congestive heart failure: effects on body weight, edema, and electrolyte excretion. Torsemide Investigators Group. Pharmacotherapy 1994;14:51421.

90. Brater DC. Diuretic therapy. N Engl J Med 1998;339:387-95. 
91. de Giuli F, Khaw KT, Cowie MR, Sutton GC, Ferrari R, Poole-Wilson PA. Incidence and outcome of persons with a clinical diagnosis of heart failure in a general practice population of 696,884 in the United Kingdom. Eur J Heart Fail 2005;7:295-302.

92. Davies MK, Hobbs FDR, Davis RC, Kenkre JE, Roalfe AK, Hare R, Wosornu D, Lancashire RJ. Prevalence of left ventricular systolic dysfunction and heart failure in the general population: main findings from the ECHOES (Echocardiographic Heart of England Screening) Study.;358:439-445.

93. Cleland JG, Cohen-Solal A, Aguilar JC, Dietz R, Eastaugh J, Follath F, Freemantle N, Gavazzi A, van Gilst WH, Hobbs FD, Korewicki J, Madeira HC, Preda I, Swedberg K, Widimsky J; IMPROVEMENT of Heart Failure Programme Committees and Investigators. Improvement programme in evaluation and management; Study Group on Diagnosis of the Working Group on Heart Failure of The European Society of Cardiology. Management of heart failure in primary care (the IMPROVEMENT of Heart Failure Programme): an international survey. Lancet. 2002;360:1631-9.

94. Hjerpe P, Merlo J, Ohlsson H, Bengtsson Boström K, Lindblad U. Validity of registration of ICD codes and prescriptions in a research database in Swedish primary care: a cross-sectional study in Skaraborg primary care database. BMC 2010;10:23.

95. Biermann J, Neumann T, Angermann CE, Erbel R, Maisch B, Pittrow D, RegitzZagrosek V, Scheffold T, Wachter R, Gelbrich G, Wasem J, Neumann A; German Competence Network Heart Failure. Economic burden of patients with various etiologies of chronic systolic heart failure analyzed by resource use and costs. Int J Cardiol 2012;156:323-5.

96. Lindström K, Engström S, Bengtsson C, Borgquist L. Determinants of hospitalisation rates: does primary health care play a role? Scand J Prim Health Care. 2003;21:15-20.

97. Watz R, Ekstrand AB, Engelbrektsson V, Beermann B. Treatment with angiotensin II antagonists and beta-blockers in an unselected group of patients with chronic heart failure. Eur J Clin Pharmacol 2005;61:209-214.

98. McAlister FA, Stewart S, Ferrua S, McMurray JJ. Multidisciplinary strategies for the management of heart failure patients at high risk for admission: a systematic review of randomized trials. J Am Coll Cardiol 2004;44:810-9.

99. Roccaforte R, Demers C, Baldassarre F, Teo KK, Yusuf S. Effectiveness of comprehensive disease management programmes in improving clinical outcomes in heart failure patients. A meta-analysis. Eur J Heart Fail. 2005;7:1133-44.

100. Gjesing A, Schou M, Torp-Pedersen C, Køber L, Gustafsson F, Hildebrandt P, Videbæk L, Wiggers H, Demant M, Charlot M, Gislason GH. Patient adherence to evidencebased pharmacotherapy in systolic heart failure and the transition of follow-up from specialized heart failure outpatient clinics to primary care. Eur J Heart Fail 2013;15:671-8.

101. Strömberg A, Mårtensson J, Fridlund B, Levin LA, Karlsson JE, Dahlström U. Nurseled heart failure clinics improve survival and self-care behaviour in patients with heart failure: results from a prospective, randomised trial. Eur Heart J 2003;24:1014-23.

102. Jaarsma T, van der Wal MH, Lesman-Leegte I, Luttik ML, Hogenhuis J, Veeger NJ, Sanderman R, Hoes AW, van Gilst WH, Lok DJ, Dunselman PH, Tijssen JG, Hillege HL, van Veldhuisen DJ; Coordinating Study Evaluating Outcomes of Advising and 
Counseling in Heart Failure (COACH) Investigators. Effect of moderate or intensive disease management program on outcome in patients with heart failure: Coordinating Study Evaluating Outcomes of Advising and Counseling in Heart Failure (COACH). Arch Intern Med 2008;168:316-24.

103. Schou M, Gustafsson F, Videbaek L, Tuxen C, Keller N, Handberg J, Sejr Knudsen A, Espersen G, Markenvard J, Egstrup K, Ulriksen H, Hildebrandt PR; NorthStar Investigators, all members of The Danish Heart Failure Clinics Network. Extended heart failure clinic follow-up in low-risk patients: a randomized clinical trial (NorthStar). Eur Heart J 2013;34:432-42.

104. Peters-Klimm F, Campbell S, Hermann K, Kunz CU, Müller-Tasch T, Szecsenyi J; Competence Network Heart Failure. Case management for patients with chronic systolic heart failure in primary care: the HICMan exploratory randomised controlled trial. Trials 2010;11:56.

105. Stewart S, Carrington MJ, Marwick TH, Davidson PM, Macdonald P, Horowitz JD, Krum H, Newton PJ, Reid C, Chan YK, Scuffham PA. Impact of home versus clinicbased management of chronic heart failure: the WHICH? (Which Heart Failure Intervention Is Most Cost-Effective \& Consumer Friendly in Reducing Hospital Care) multicenter, randomized trial. J Am Coll Cardiol 2012;60:1239-48.

106. Liao L, Anstrom KJ, Gottdiener JS, Pappas PA, Whellan DJ, Kitzman DW, Aurigemma GP, Mark DB, Schulman KA, Jollis JG. Long-term costs and resource use in elderly participants with congestive heart failure in the Cardiovascular Health Study. Am Heart J 2007;153:245-52.

107. Rydén-Bergsten T, Andersson F. The healthcare costs of heart failure in Sweden. J Intern Med 1999;246:275-84.

108. Stewart S, Jenkins A, Buchan S, McGuire A, Capewell S, McMurray JJ. The current cost of heart failure to the National Health Service in the UK. Eur J Heart Fail. 2002;4:361-71.

109. Liao L, Allen LA, Whellan DJ. Economic burden of heart failure in the elderly. Pharmacoeconomics 2008;26:447-62.Krumholz HM, Parent EM, Tu N, Vaccarino V, Wang Y, Radford MJ, Hennen J. Readmission after hospitalization for congestive heart failure among Medicare beneficiaries. Arch Intern Med. 1997;157:99-104.

110. Stålhammar J, Stern L, Linder R, Sherman S, Parikh R, Ariely R, Wikström G. Resource utilization and cost of heart failure associated with reduced ejection fraction in Swedish patients. J Med Econ 2012;15:938-46.

111. Mejhert M, Lindgren P, Schill O, Edner M, Persson H, Kahan T. Long term health care consumption and cost expenditure in systolic heart failure. Eur J Intern Med 2013;24:260-5.

112. Postmus D, Pari AA, Jaarsma T, Luttik ML, van Veldhuisen DJ, Hillege HL, Buskens E. A trial-based economic evaluation of 2 nurse-led disease management programs in heart failure. Am Heart J 2011;162:1096-104.

113. Berry C, Murdoch DR, McMurray JJ. Economics of chronic heart failure. Eur J Heart Fail. 2001;3:283-91. 
114. Krumholz HM, Parent EM, Tu N, Vaccarino V, Wang Y, Radford MJ, Hennen J. Readmission after hospitalization for congestive heart failure among Medicare beneficiaries. Arch Intern Med. 1997;157:99-104.

115. Yamokoski LM, Hasselblad V, Moser DK, Binanay C, Conway GA, Glotzer JM, Hartman KA, Stevenson LW, Leier CV. Prediction of rehospitalization and death in severe heart failure by physicians and nurses of the ESCAPE trial. J Card Fail. 2007;13:8-13.

116. Mejhert M, Persson H, Edner M, Kahan T. Epidemiology of heart failure in Sweden--a national survey. Eur J Heart Fail 2001;3:97-103.

117. Bardsley M, Steventon A, Doll H. Impact of telehealth on general practice contacts: findings from the whole systems demonstrator cluster randomised trial. BMC Health Serv Res 2013;13:395.

118. Östgren CJ, Johansson A, Grip B, Johansson A, Heurgren M, Melander A. Diabetessjukvård resurskrävande i primärvården. Läkartidningen 2003;100:3600-4.

119. Strömberg A, Ahlén H, Fridlund B, Dahlström U. Interactive education on CD-ROMa new tool in the education of heart failure patients. Patient Educ Couns 2002;46:75-81.

120. Choy AM, Darbar D, Lang CC, Pringle TH, McNeill GP, Kennedy NS, Struthers AD. Detection of left ventricular dysfunction after acute myocardial infarction: comparison of clinical, echocardiographic, and neurohormonal methods. Br Heart J 1994;72:16-22.

121. Van Royen N, Jaffe CC, Krumholz HM, Johnson KM, Lynch PJ, Natale D, Atkinson P, Deman P,Wackers FJ. Comparison and reproducibility of visual echocardiographic and quantitative radionuclide left ventricular ejection fractions. Am J Cardiol 1996;77:843850.

122. Karl J, Borgya A, Gallusser A, Huber E, Krueger K, Rollinger W, Schenk J.

Development of a novel, N-terminal-proBNP (NT-proBNP) assay with a low detection limit. Scand J Clin Lab Invest Suppl. 1999;230:177-81.

123. Sullivan M, Karlsson J Ware J. The Swedish SF-36 Health Survey-I. Evaluation of data quality, scaling assumptions, reliability and construct validity across general populations in Sweden, Soc Sci Med 1995;41:1349-58.

124. Taylor AL, Ziesche S, Yancy C, Carson P, D'Agostino R Jr, Ferdinand K, Taylor M, Adams K, Sabolinski M, Worcel M, Cohn JN; African-American Heart Failure Trial Investigators. Combination of isosorbide dinitrate and hydralazine in blacks with heart failure. N Engl J Med 2004;351:2049-57.

125. Nixon RM, Thompson SG. Parametric modelling of cost data in medical studies. Stat Med 2004;23:1311-31.

126. Greenland S. Dose-response and trend analysis in epidemiology: alternatives to categorical analysis. Epidemiology 1995;6:356-65.

127. Doughty RN, Wright SP, Pearl A, Walsh HJ, Muncaster S, Whalley GA, Gamble G, Sharpe N. Randomized, controlled trial of integrated heart failure management: The Auckland Heart Failure Management Study. Eur Heart J 2002;23:139-46.

128. Hershberger RE, Nauman DJ, Byrkit J, Gillespie G, Lackides G, Toy W, Burgess D, Dutton D. Prospective evaluation of an outpatient heart failure disease management program designed for primary care: the Oregon model. J Card Fail 2005;11:293-8. 
129. van Jaarsveld CH, Ranchor AV, Kempen GI, Coyne JC, van Veldhuisen DJ, Sanderman R. Epidemiology of heart failure in a community-based study of subjects aged $>$ or $=57$ years: incidence and long-term survival. Eur J Heart Fail 2006;8:23-30.

130. Persson H, Erntell H, Eriksson B, Johansson G, Swedberg K, Dahlstrom U. Improved pharmacological therapy of chronic heart failure in primary care: a randomized Study of NT-proBNP Guided Management of Heart FailuredSIGNAL-HF (Swedish Intervention studydGuidelines and NT-proBNP AnaLysis in Heart Failure). Eur J Heart Fail 2010;12:1300-8.

131. Jenkinson C1, Jenkinson D, Shepperd S, Layte R, Petersen S. Evaluation of treatment for congestive heart failure in patients aged 60 years and older using generic measures of health status (SF-36 and COOP charts). Age Ageing 1997;26:7-13.

132. Göhler A, Conrads-Frank A, Worrell SS, Geisler BP, Halpern EF, Dietz R, Anker SD, Gazelle GS, Siebert U. Decision-analytic evaluation of the clinical effectiveness and cost-effectiveness of management programmes in chronic heart failure. Eur J Heart Fail 2008;10:1026-32. 


\section{Papers}

The articles associated with this thesis have been removed for copyright reasons. For more details about these see:

http://urn.kb.se/resolve?urn=urn:nbn:se:liu:diva-104954 